University of Nebraska - Lincoln

DigitalCommons@University of Nebraska - Lincoln

Faculty Publications: Department of Entomology

Entomology, Department of

2008

\title{
A Synopsis of Nebraska Grasshopper Distributions
}

\author{
Mathew L. Brust \\ University of Nebraska-Lincoln, mbrust@csc.edu \\ William Wyatt Hoback \\ University of Nebraska at Kearney, whoback@okstate.edu \\ Robert J. Wright \\ University of Nebraska-Lincoln, rwright2@unl.edu
}

Follow this and additional works at: https://digitalcommons.unl.edu/entomologyfacpub

Part of the Entomology Commons

Brust, Mathew L.; Hoback, William Wyatt; and Wright, Robert J., "A Synopsis of Nebraska Grasshopper Distributions" (2008). Faculty Publications: Department of Entomology. 163.

https://digitalcommons.unl.edu/entomologyfacpub/163

This Article is brought to you for free and open access by the Entomology, Department of at DigitalCommons@University of Nebraska - Lincoln. It has been accepted for inclusion in Faculty Publications: Department of Entomology by an authorized administrator of DigitalCommons@University of Nebraska - Lincoln. 


\title{
A Synopsis of Nebraska Grasshopper Distributions
}

\author{
Mathew L. Brust, ${ }^{1}$ W. Wyatt Hoback, ${ }^{2, *}$ and Robert J. Wright ${ }^{1}$
}

\begin{abstract}
Between 2005 and 2007, 656 new county records and eight new state records were obtained for Nebraska's short-horned grasshoppers (Acrididae and Romaleidae). This represents an increase of $30 \%$ in the known grasshopper county records in Nebraska. Based on the large number of new distribution records, it appears that the previous distributions of Nebraska's grasshoppers greatly underestimated the actual distributions. The new grasshopper state records were: Boopedon gracile, Chloealtis abdominalis, Encoptolophus subgracilis, Melanoplus bispinosus, Melanoplus borealis, Melanoplus punctulatus, Paratylotropidia brunneri, and Psinidia fenestralis were obtained. These new records will aid in both grasshopper monitoring for pest outbreaks and in conservation of rare and declining species which are often habitat specialists associated with prairie ecosystems.

KEY WORDS: Acrididae, county record, state record, grasshopper distribution
\end{abstract}

Over 100 species of short-horned grasshoppers (Acrididae and Romaleidae) are known to occur in Nebraska. However, no publication has thoroughly documented the distribution and general life histories of Nebraska's grasshoppers since Hauke (1953). Hagen and Rabe (1991) updated Hauke's records and provide distribution maps for 92 species of Nebraska grasshoppers generated through the U.S. Department of Agriculture's rangeland grasshopper sampling from 1988 to 1991. As of 1991, there were 2,185 county records for the short-horned grasshoppers of Nebraska. Such works are important, because future studies require baseline information against which to compare distributions and abundances. In addition, because large amounts of the Great Plains have been converted to row crop agriculture, the conservation of rare grasshopper species has become a reality across the eastern United States (Kirk and Bomar, 2005).

The large number of grasshopper species (Orthoptera: Acridae and Romaleidae) occurring in Nebraska is likely the result of several ecological zones converging within the state. Annual precipitation ranges from over $86 \mathrm{~cm}$ in the southeastern corner of the state to less than $40 \mathrm{~cm}$ in the westernmost areas. This results in a number of ecological zones in the state, including deciduous forest, and large expanses of tallgrass, mixed-grass, and shortgrass prairie (Omernik, 1987; Omernik, 1995; Bailey, 1995). In high elevation areas such as in the Pine Ridge, (over $1500 \mathrm{~m}$ ) a few western mountain-dwelling species occur. As a result of these various habitats, Nebraska, is home to species typical of eastern woodlands as well as semiarid western habitats.

In addition, it is possible that other species have expanded their ranges as a result of indirect human changes. Some grasshoppers are adapted to live in trees as well as among plants in forested areas, and it is likely that a few sylvan species have expanded their range westward along riverine corridors in valleys such as that of the

\footnotetext{
${ }^{1}$ Department of Entomology, University of Nebraska Lincoln, 202 Plant Industry Building, Lincoln, NE 68583-0816

${ }^{2}$ Department of Biology, University of Nebraska at Kearney, 905 W 25th Street, Kearney, NE 68849

* Author to whom proofs should be sent, email: hobackww@unk.edu, phone: (308) 865-8602
} 
Platte River as these areas have become more wooded in recent decades (Johnson, 1994). At least two species appear to have adapted to human disturbance and spread eastward. The acridid Hadrotettix trifasciatus (Say) and Spharagemon equale (Say), both of which utilize habitats with abundant open soil, such as in areas of excavation for earthen materials at the eastern edge of their range.

Several acridid species appear to have been frequently overlooked in collections as a result of their early or late seasonal adult activity, habitat specialization, a preference for habitats other than rangeland, or difficulty of identification. Noteworthy examples include Boopedon gracile Rehn, Encoptolophus subgracilis Caudell, Melanoplus bispinosus Scudder, Melanoplus discolor (Scudder), Melanoplus flavidus Scudder, Paratylotropidia brunneri Scudder, Pardalophora apiculata (Harris), Psinidia fenestralis (Serville), Syrbula admirabilis Uhler, and Trimerotropis maritima (Harris).

It is unfortunate that the original distribution of most eastern grasshopper species will likely never be known. This fact is largely related to their status as general pests, and thus, unlikely to be collected by most. This is obvious in the case of the Rocky Mountain locust (Melanoplus spretus (Walsh)), which once ravaged the central United States in enormous swarms. It became extinct (but see Lockwood, 2004) around 1900, and specimens are extremely rare in collections.

Other less common species are likely to become extirpated with little notice. For example, one species mentioned by Bruner (1897) as not uncommon in eastern Nebraska in lowland areas may be extirpated. Melanoplus borealis (Fieber) has not been collected since Bruner's time (1897), and the low meadows which it likely occupied across eastern Nebraska have been almost completely eliminated.

The work reported in this paper is the result of specimens obtained in sweepnet surveys by the U.S. Department of Agriculture Animal Plant Health Inspection Service (USDA APHIS) which occur in rangelands across the western two thirds of Nebraska. In addition, personal collecting by the senior author sampled grasshoppers in a wide variety of habitats throughout the state. The objective of this study was to obtain a thorough knowledge of the distribution of the shorthorned grasshoppers of Nebraska, including limits of distribution.

\section{Materials and Methods}

From 2005 to 2007, extensive surveys for grasshoppers were conducted across Nebraska (Fig. 2). Sweep samples were obtained from approximately 800 rangeland sites selected by USDA-APHIS across the western two-thirds of the state. In addition, specialized collections were made in a wide variety of habitats across the state but with the majority in rangeland habitats. Collections from the more specialized surveys targeted specific microhabitats not often found in typical rangeland surveys.

Adult specimens from all related collections were identified to species, and late instar nymphs of easily identified species were also identified. Identifications to species were made using a variety of resources including Otte (1981; 1984), Helfer (1987), Pfadt (2002), and Song (2004). Voucher specimens were kept for all new county and state records. All voucher specimens from this study are currently housed in the collection at USDA-APHIS in Lincoln, Nebraska.

Specimens in the Nebraska State Museum were also examined. The primary objective of this examination was to verify previous identification, particularly of 
taxa that are notoriously difficult to identify. As a result, some new county records listed here represent specimens from older collections not listed in previous publications as a result of previous misidentification or changes in nomenclature.

\section{Results and Discussion}

A total of 656 new county and eight new state records were established for Nebraska acridids (based on Hauke (1953); Hagen (1970); and Hagen and Rabe (1991) (Figs. 3-13). Of the seven new state records, two appear to be species that were previously overlooked. Melanoplus bispinosus has now been recorded from nine counties, and Psinidia fenestralis is now known from three counties. Bruner (1897) reported collecting $P$. fenestralis from northwestern Nebraska, but this record is unlikely and was later disregarded by Hebard (1925). In addition, Bruner stated that these specimens had yellow hind wings. All recent collections from Nebraska possess red hind wings. This species has, however, been found as far west as central Kansas (Hebard, 1931).

Encoptolophus subgracilis is only known from three populations in or near Lincoln. These locations were discovered in 2006 and 2007 and this species appears associated with alkaline and saline areas. Paratylotropidia brunneri has only been collected from two partially wooded sites in the southeastern corner of the state. The previous occurrence of Bruneria brunnea (Thomas) is only known from Bruner (1897), but a series of seven specimens was collected at Monroe Canyon in Sioux County in 2006, reestablishing its occurrence in the state. A single specimen of Melanoplus punctulatus Scudder was collected from a wooded area in Richardson County in 2007. It was reported to occur in small numbers in oak groves in the extreme eastern part of Nebraska (Bruner, 1897). Trimerotropis salina McNeill is in severe decline at the type location (Lincoln, Nebraska) (Otte, 1984), and we estimate that fewer than 100 individuals occur yearly. It is, however, abundant around the Saline lakes in Sheridan and Morrill Counties and it is speculated that it might occur into northwestern Garden County based on the occurrence of saline habitats.

Re-examination of material in the University of Nebraska State Museum collection revealed a number of previously unpublished records. Several new records were the result of previous misidentifications. A single specimen of Spharagemon bolli Scudder from Douglas County was previously identified as Encoptolophus sordidus (Burmeister) (collected 1935) and represents only the second record for the eastern part of the state. The record presented for Chloealtis abdominalis (Thomas) is interesting, because if correct, it is a southward extension for the species. The lone Nebraska specimen was collected in Knox County by W. D. Pierce in 1902. As is normal for this species, the Knox County specimen lacks the dark patch on the lateral areas of the pronotum as well as the light markings on the outer hind femur. Because of the distance from known populations (over $600 \mathrm{~km}$ ) (Otte, 1981; Capinera et al., 2004), this record of a boreal species is best considered questionable.

Boopdeon gracile is an interesting case because recent literature (Hagen and Rabe, 1991) listed the older records as Boopedon nubilum (Say). The specimens were collected by H. Hauke in 1932 and 1949 in Nuckolls and Thayer Counties and were listed as Boopedon maculatum Caudell in Hauke's 1953 publication. Boopedon maculatum later became a synonym of $B$. nubilum. It is likely that forms called $B$. maculatum represented more than one entity, and those which Hauke called $B$. 
maculatum were in fact, B. gracile. This species has since been collected in Franklin, Gage, Pawnee, and Richardson Counties.

Hauke (1953) stated that no specimens of Trimerotropis maritima (Harris) existed in the collection at the Nebraska State Museum. However, upon our review, several examples were found in the collection, all of which predated his manuscript. This species has since been found to be common in sandy areas along streams and rivers across much of Nebraska and is abundant along the Platte River.

The occurrences of two additional species in Nebraska are, at this time, controversial. Melanoplus fluviatilis Bruner was mentioned in Bruner (1893) as an unknown species, and identified by Bruner in 1897 as this species (Bruner, 1897). Bruner did not describe the species in detail, nor was the brief description published in a recognized scientific journal. Blatchley (1920), however, gives an adequate description of this form. Subsequent authors have considered this form to be a subspecies of Melanoplus foedus (Scudder).

Recent work on this form in Nebraska provide good evidence for its status as a full species, including consistent morphological, habitat, and behavioral characteristics, as well as a lack of introgression even where it (rarely) co-occurs with $M$. foedus. The male cerci of this form are virtually identical to both $M$. foedus and Melanoplus packardii Scudder, and the furculae appear intermediate between the two species. The furculae are distinctly shorter than those of $M$. foedus but not as irregular in shape as in M. packardii. The shape of the aedeagus is generally similar to that of $M$. foedus (Brust et al., unpublished), but further examination may reveal distinct differences. Analyses of nuclear DNA are currently being performed (M. Brust unpublished).

The general appearance of the adults also easily separate the two forms because M. foedus is generally orangish-brown with lighter markings, distinct light lateral stripes on the dorsal pronotum, poorly developed postocular bars, and specimens nearly always have pinkish-red tibiae. The adults of $M$. fluviatilis are woody-brown in color, lack stripes on the dorsal pronotum, have well developed and usually black postocular bars, and may have blue, purple, or pinkish-red tibiae in approximately equal proportions. The ranges of these two forms overlap broadly (Fig. 1), and yet apparent intergrades have only been found at one Nebraska location.

Specimens from the Melanoplus packardii group are commonly misidentified, and it is estimated that of those in the collection at the Nebraska State Museum, fewer than $85 \%$ were correctly identified. Several specimens that fit the description of $M$. fluviatilis were found in the collection, mostly misidentified as Melanoplus angustipennis (Dodge). Future work on this group will determine the validity of M. fluviatilis, but it is here being treated as a full species based on distinct morphological characters. If so, all records of $M$. foedus from east of Holt County will need to be reexamined as they are most likely to represent $M$. fluviatilis. Because no specimens from this group other than what appeared to be $M$. fluviatilis from these counties were found in the collection at the Nebraska State Museum, existing eastern records for $M$. foedus were disregarded.

Chortophaga australior Rehn and Hebard is known to occur only in the southeastern United States. Numerous specimens of Chortophaga viridifasciata (DeGeer) from Nebraska, especially those found later in the summer, share many characters with $C$. australior. Examination of the original description of $C$. australior, as well as other related literature, casts some doubt on the validity of 


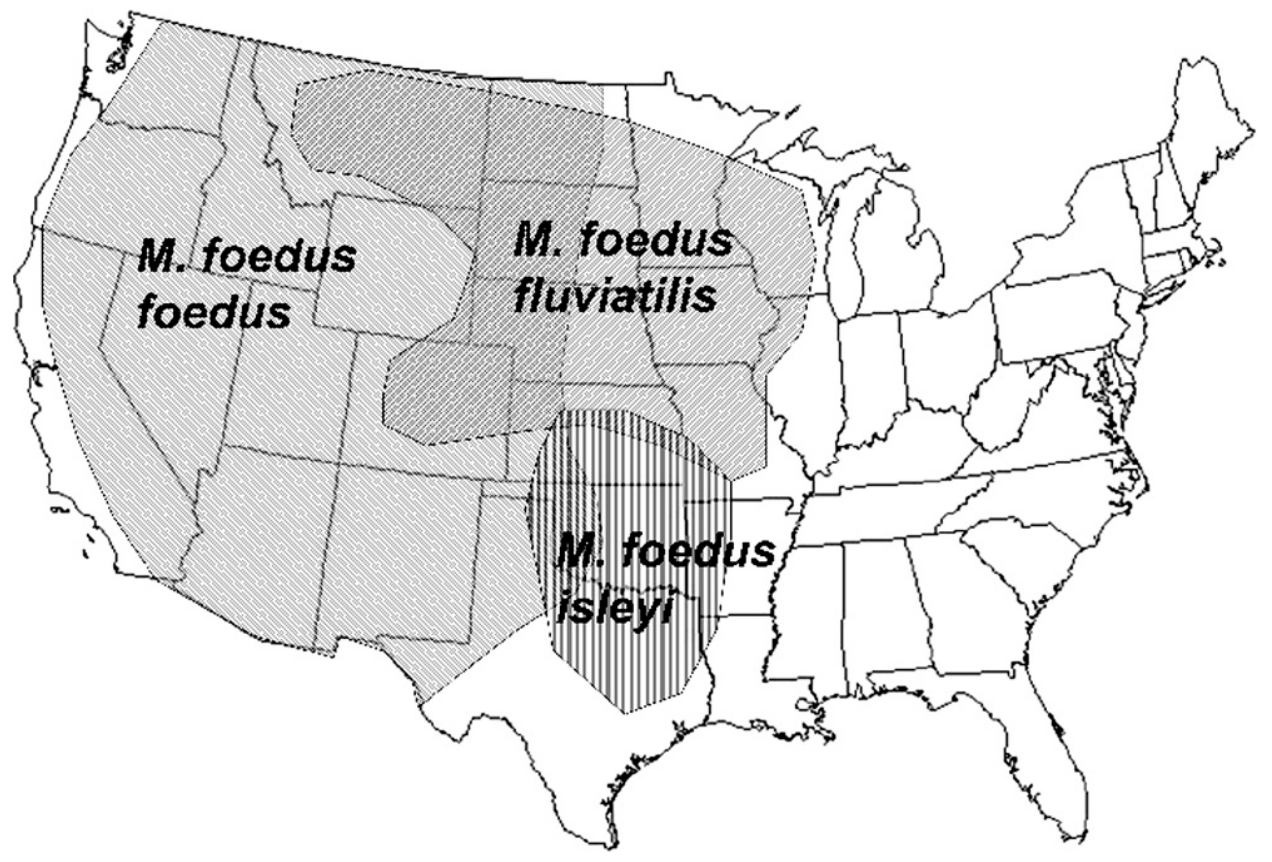

Fig. 1. Map showing the generalized United States Distribution of subspecies of Melanoplus foedus. Map based on Hebard (1928), Hebard (1929), Hebard (1931), Hebard (1932), Hebard (1934), Hebard (1936a), Hebard (1936b), Isley (1937), La Rivers (1948), Froeschner (1954), Coppock (1962), Capinera and Sechrist (1982), McDaniel (1987), Lockwood et al. (1993), Kirk and Bomar (2005), and Schell et al. (2007). In these references $M$. fluviatilis is variously referred to as Melanoplus foedus fluviatilis or Melanoplus fluviatilis. Light gray areas indicate approximate range of each subspecies and darker gray areas indicate regions of overlap between subspecies.

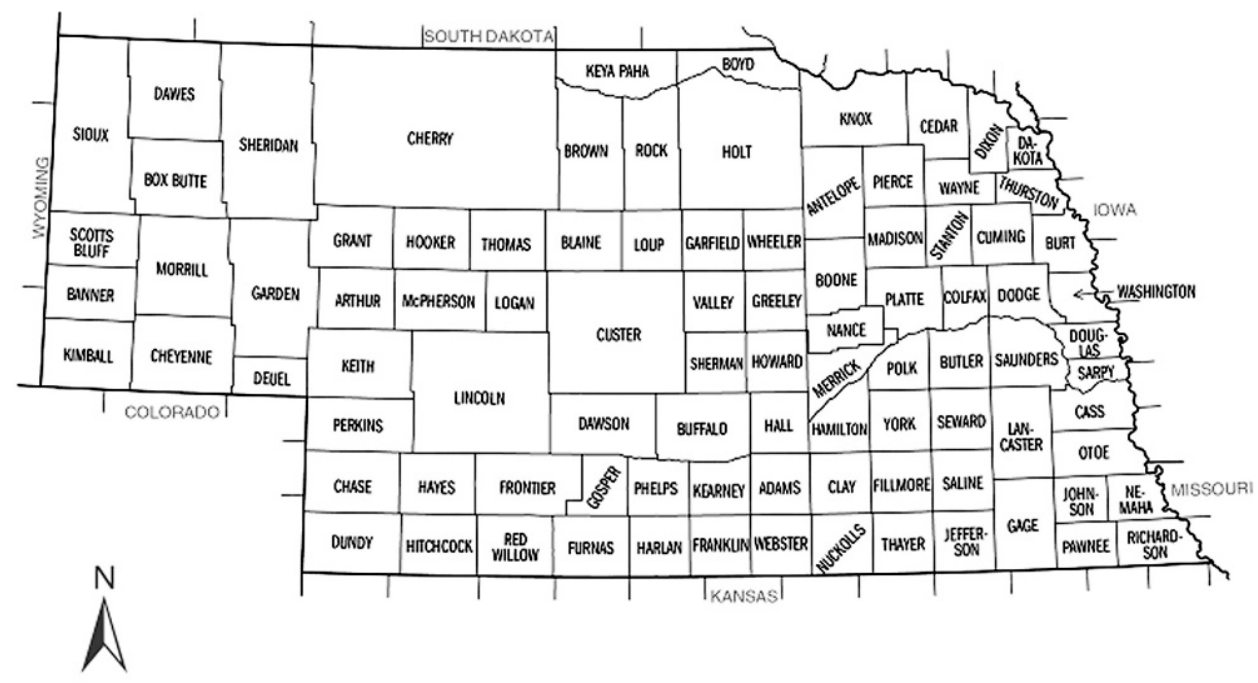

Fig. 2. Map of Nebraska counties. 


\section{Acrolophitus hirtipes (Say)}

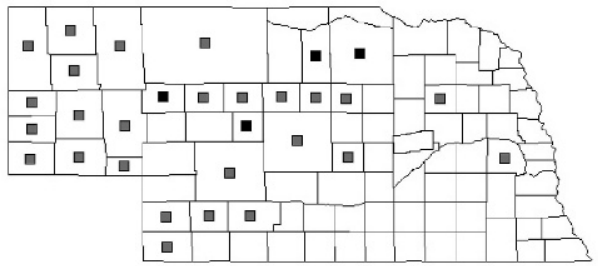

Aeropedellus clavatus (Thomas)

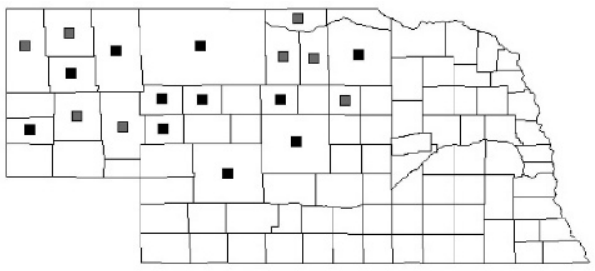

Amphitornus coloradus (Thomas)

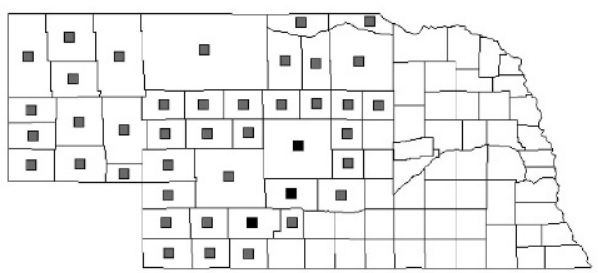

Arphia pseudonietana (Thomas)

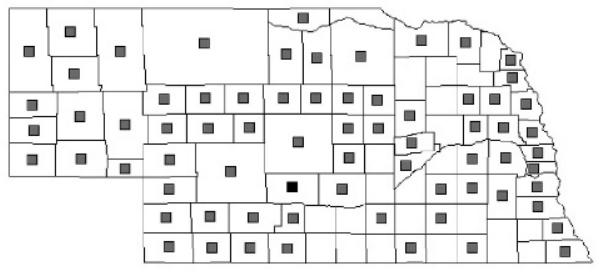

Arphia xanthoptera (Burmeister)

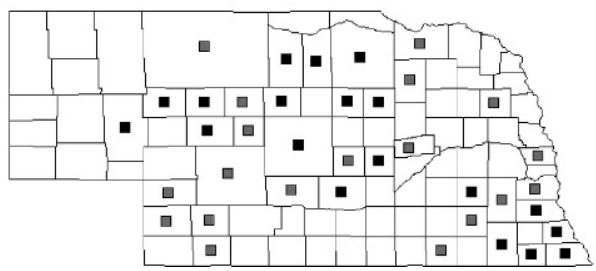

Aeoloplides turnbulli (Caudell)

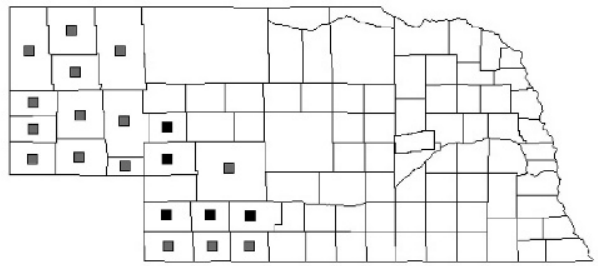

Ageneotettix deorum (Scudder)

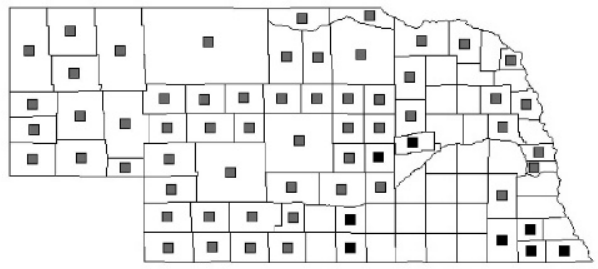

Arphia conspersa Scudder

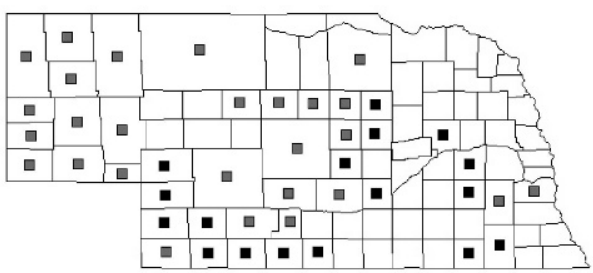

Arphia simplex Scudder

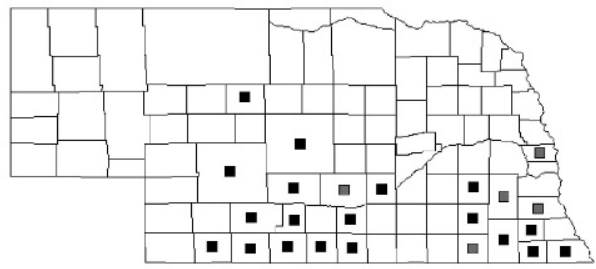

Aulocara elliotti (Thomas)

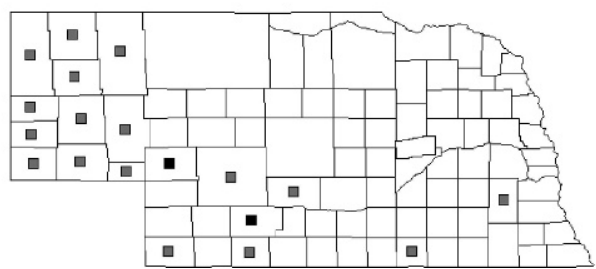

Figs. 3-13. County-level distributions of Nebraska grasshoppers. Gray squares represent records from previous literature (Bruner, 1897; Hebard, 1925; Hauke, 1953; Mulkern et al., 1969; Hagen, 1970, and Hagen and Rabe, 1991). Closed (blackened) squares represent new county records obtained during this study (2005-2006). The placement of the Saunders County record for Melanoplus fluviatilis is tentative as the type location is Ashland, Nebraska, near the edge of Saunders County. 
Aulocara femoratum Scudder

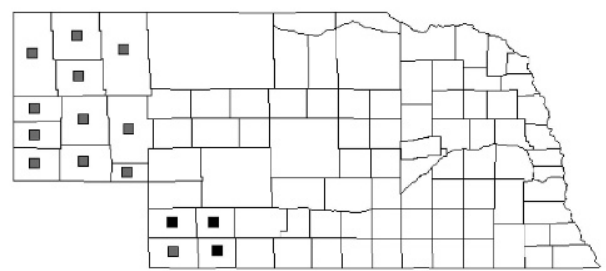

Boopedon gracile Rehn (new state record)

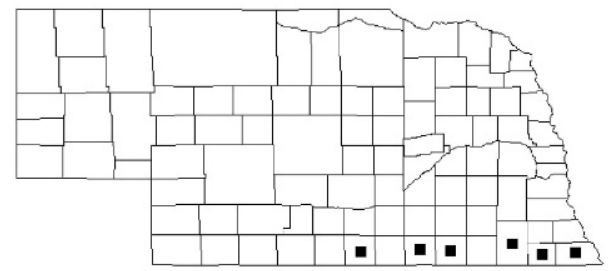

Brachystola magna (Girard)

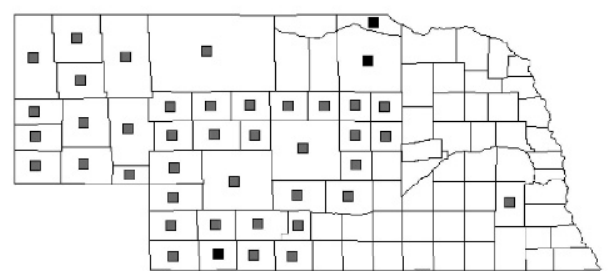

Camnula pellucida (Scudder)

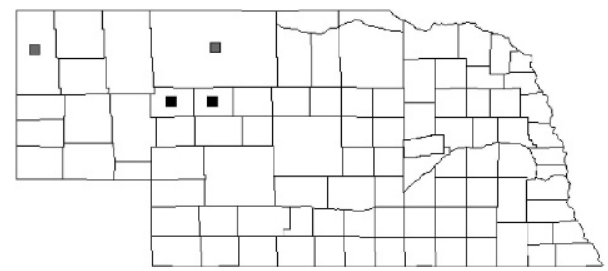

Chloealtis abdominalis (Thomas) (new state record)

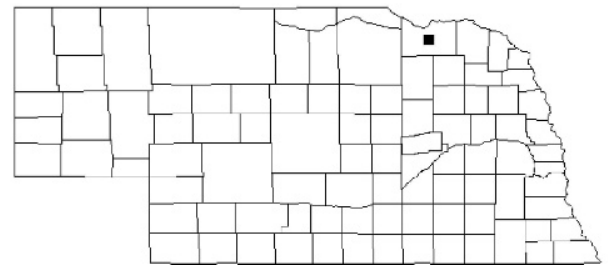

Boopedon auriventris $\mathrm{McNeill}$

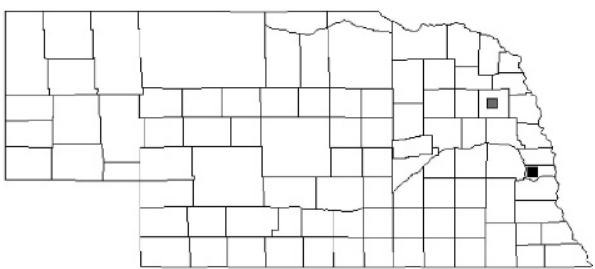

Boopedon nubilum (Say)

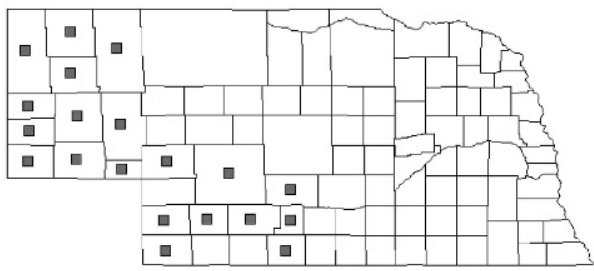

Bruneria brunnea (Thomas)

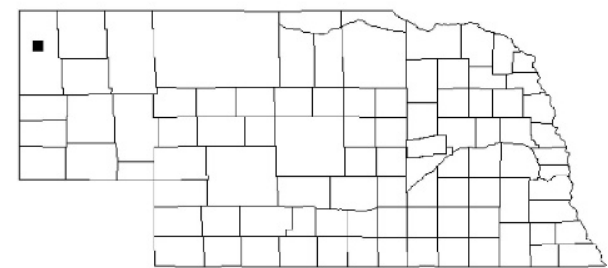

Campylacantha olivacea (Scudder)

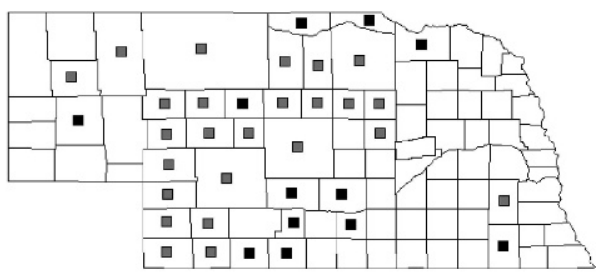

Chloealtis conspersa (Harris)

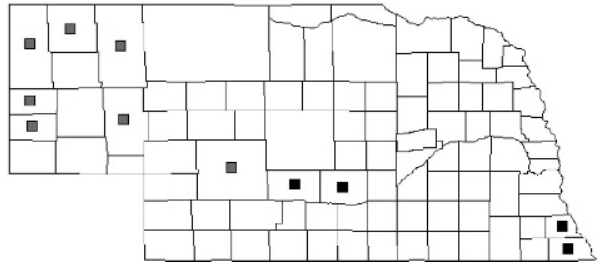

Figs. 3-13. Continued. 
Chorthippus curtipennis (Harris)

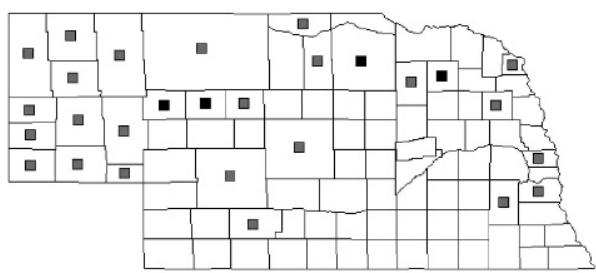

Circotettix rabula Rehn and Hebard

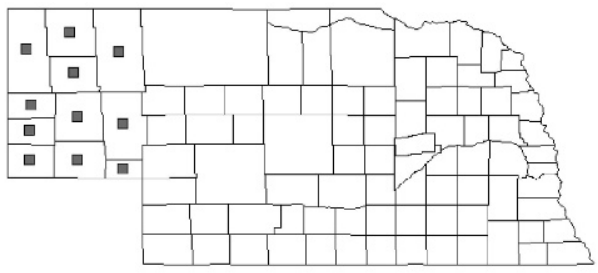

Cordillacris occipitalis (Thomas)

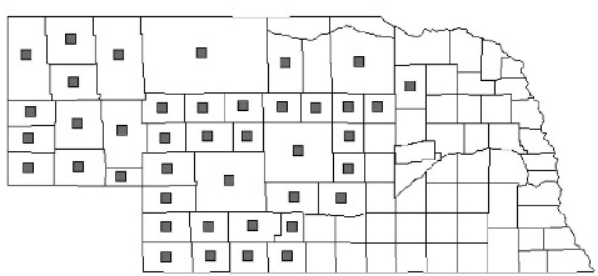

Dactylotum bicolor (Thomas)

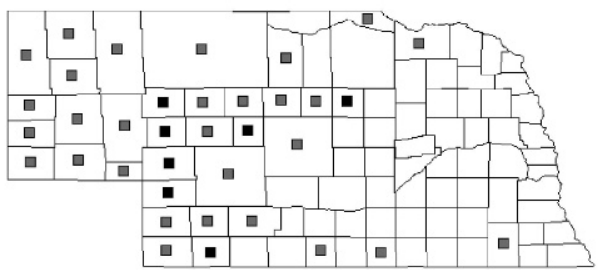

Dichromorpha viridis (Scudder)

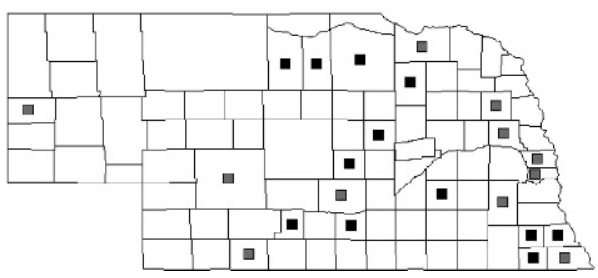

Chortophaga viridifasciata (DeGeer)

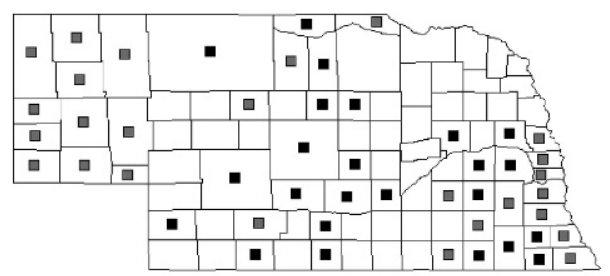

Cordillacris crenulata (Bruner)

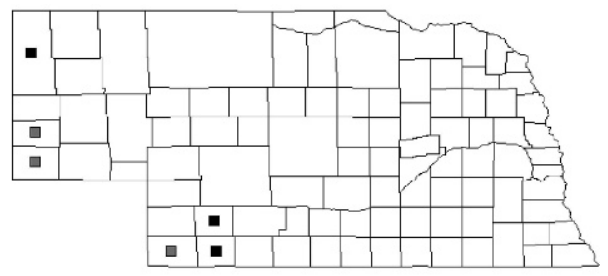

Cratypedes neglectus (Thomas)

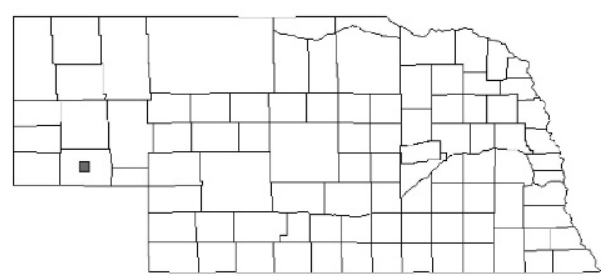

Derotmema haydeni (Say)

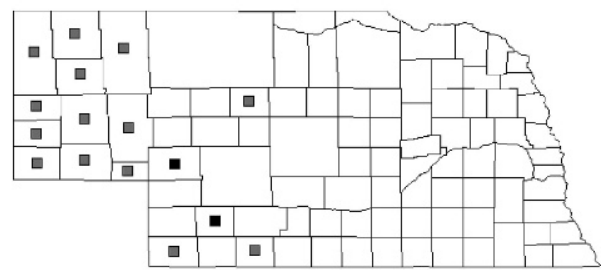

Dissosteira carolina (Linnaeus)

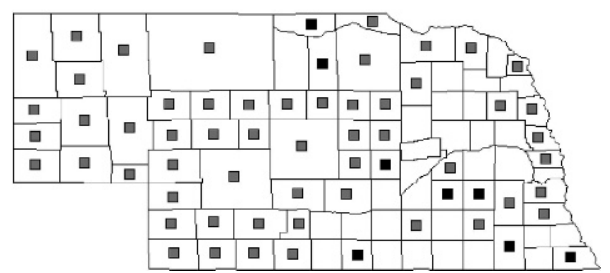

Figs. 3-13. Continued. 
Dissosteira longipennis (Thomas)

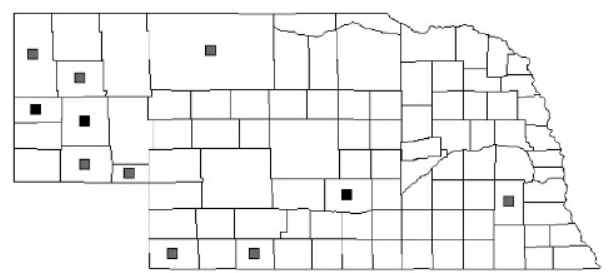

Encoptolophus sordidus (Burmeister)

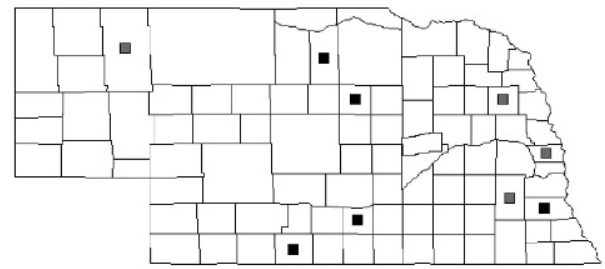

Eritettix simplex (Scudder)

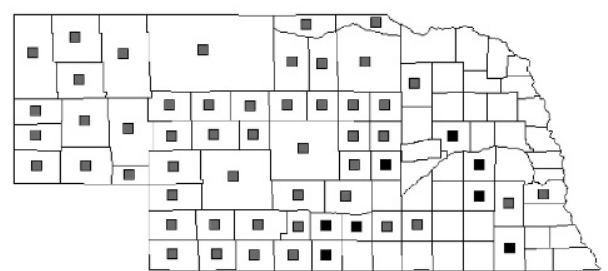

Heliaula rufa (Scudder)

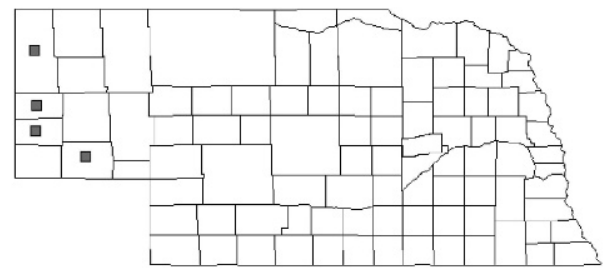

Hesperotettix viridis (Scudder)

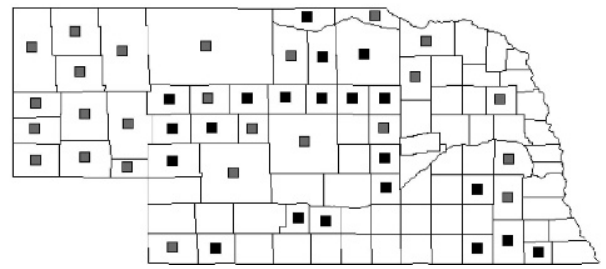

Encoptolophus costalis (Scudder)

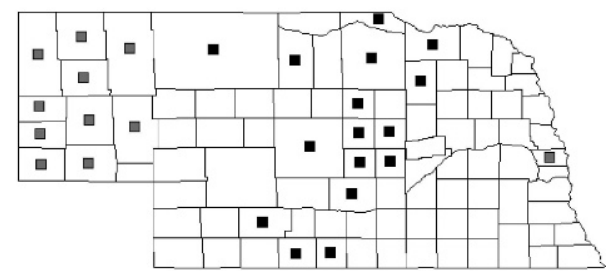

Encoptolophus subgracilis Caudell (new state record)

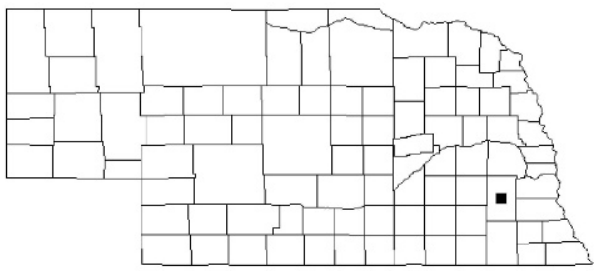

Hadrotettix trifasciatus (Say)

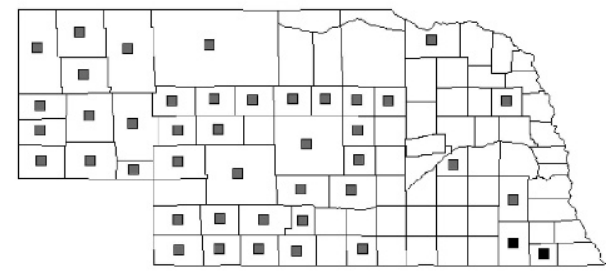

Hesperotettix speciosus (Scudder)

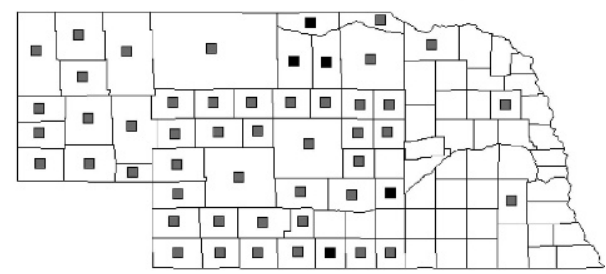

Hippiscus ocelote (Saussure)

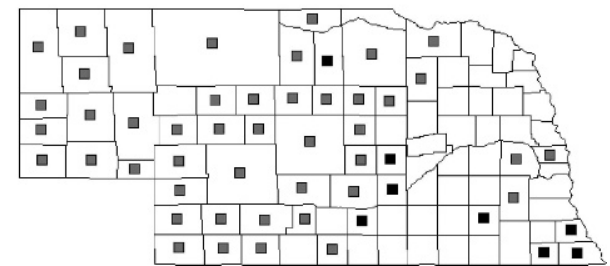

Figs. 3-13. Continued. 
Hypochlora alba (Dodge)

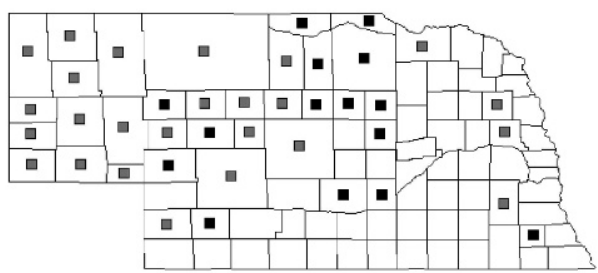

Melanoplus bispinosus Scudder (new state record)

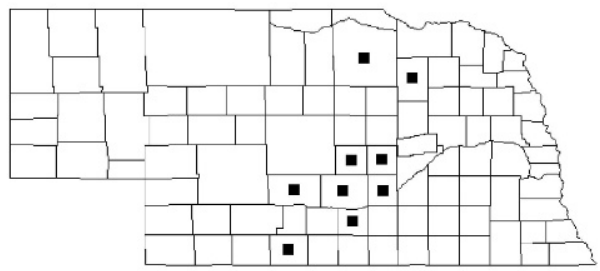

Melanoplus borealis (Fieber) (new state record)

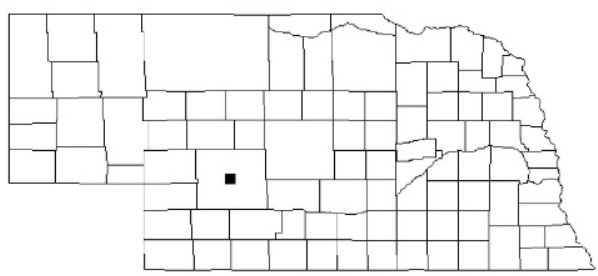

Melanoplus bruneri Scudder

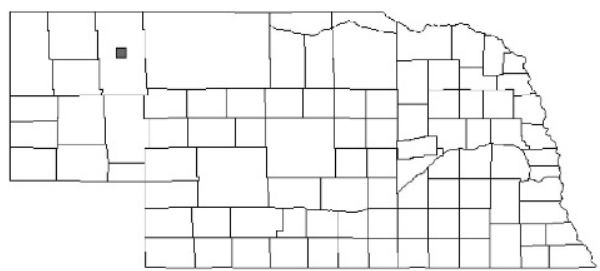

Melanoplus dawsoni (Scudder)

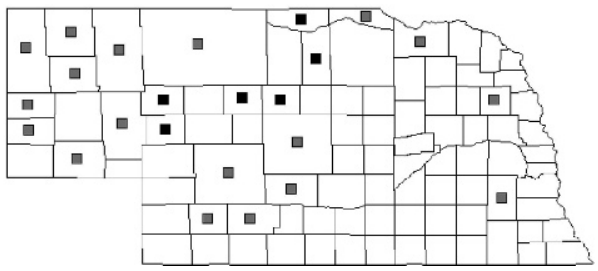

Melanoplus angustipennis (Dodge)

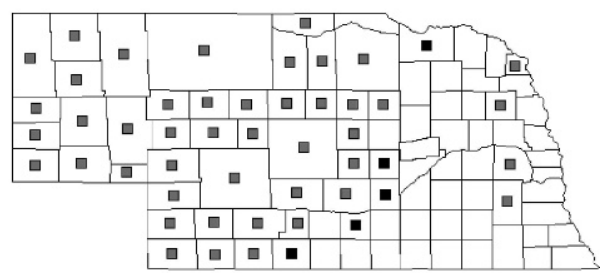

Melanoplus bivittatus (Say)

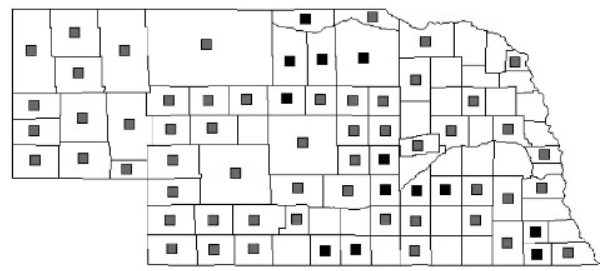

Melanoplus bowditchi Scudder

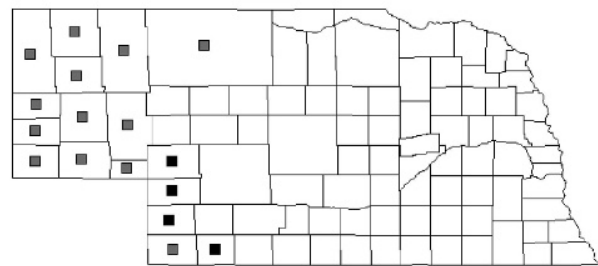

Melanoplus confusus Scudder

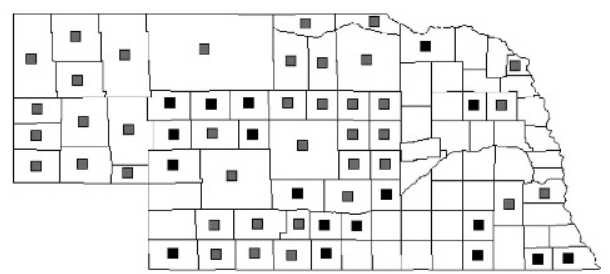

Melanoplus differentialis (Thomas)

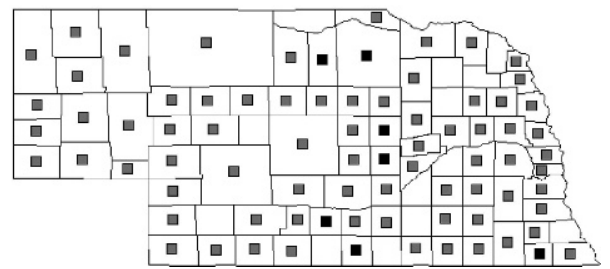

Figs. 3-13. Continued. 
Melanoplus discolor (Scudder)

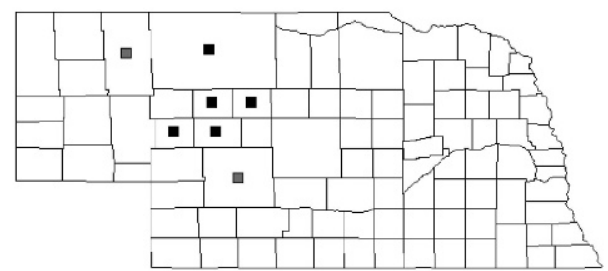

Melanoplus femurrubrum (DeGeer)

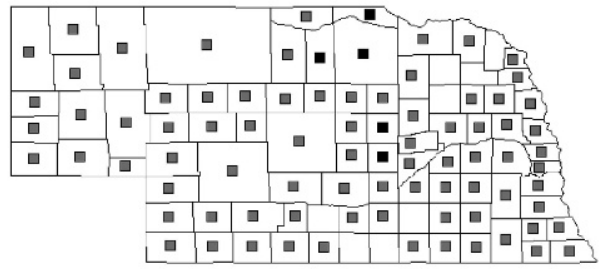

Melanoplus fluviatilis Bruner

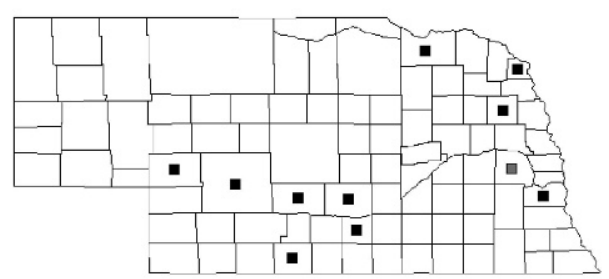

Melanoplus gladstoni Scudder

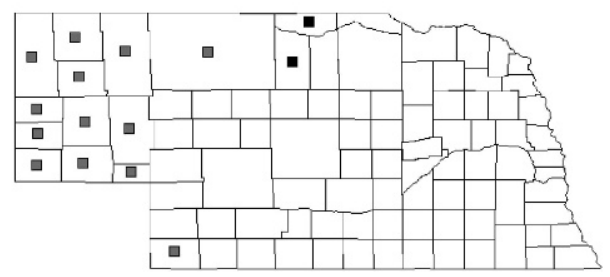

Melanoplus huroni Blatchley

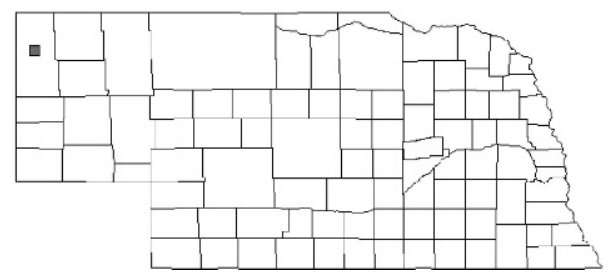

Melanoplus fasciatus (Walker)

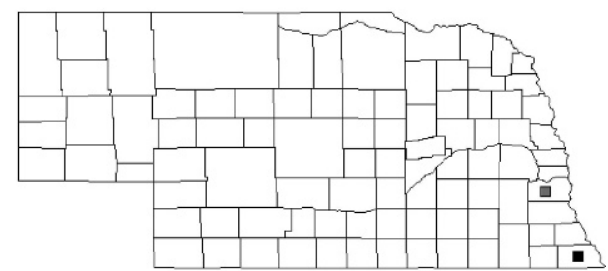

Melanoplus flavidus Scudder

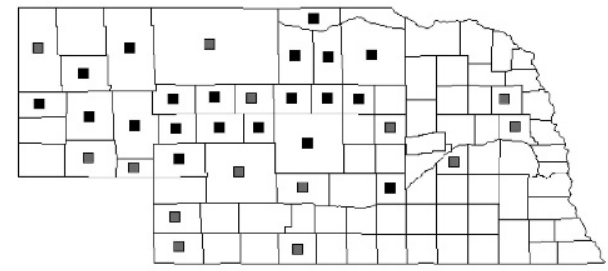

Melanoplus foedus (Scudder)

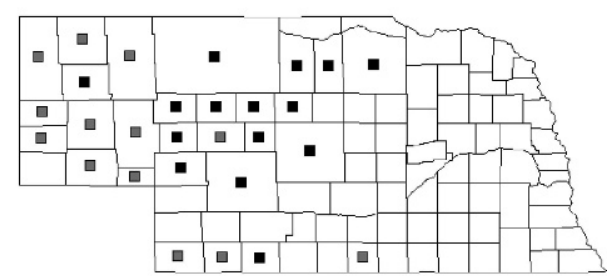

Melanoplus gracilis (Bruner)

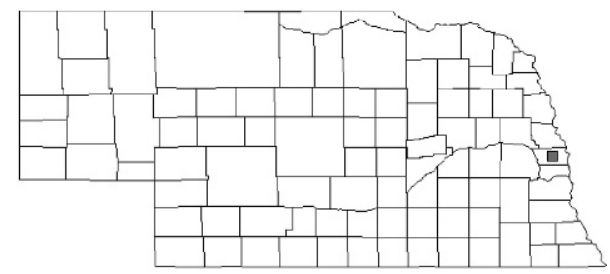

Melanoplus infantilis (Scudder)

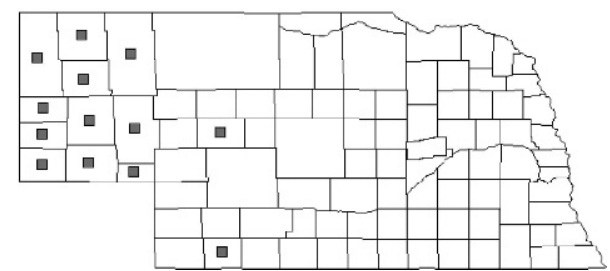

Figs. 3-13. Continued. 
Melanoplus keeleri (Thomas)

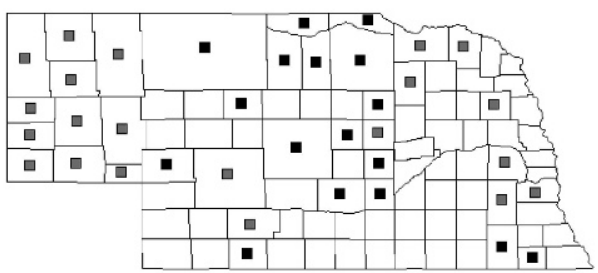

Melanoplus occidentalis (Thomas)

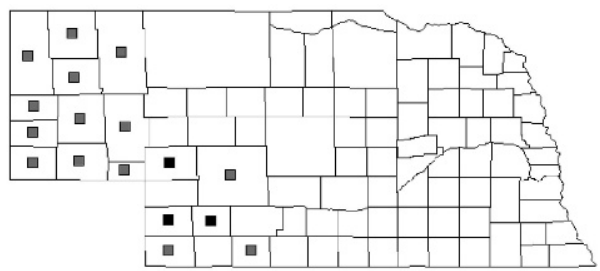

Melanoplus punctulatus Scudder (new state record)

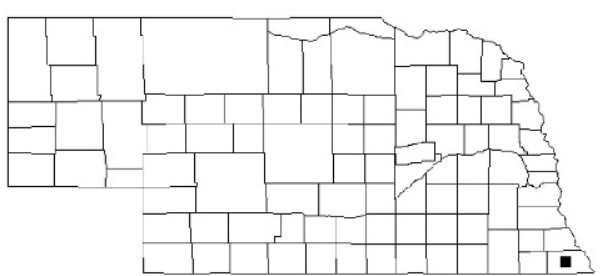

Melanoplus scudderi (Uhler)

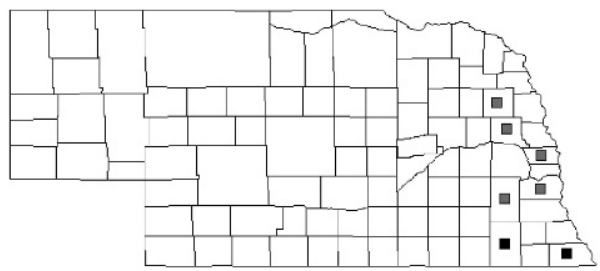

Mermiria bivittata (Serville)

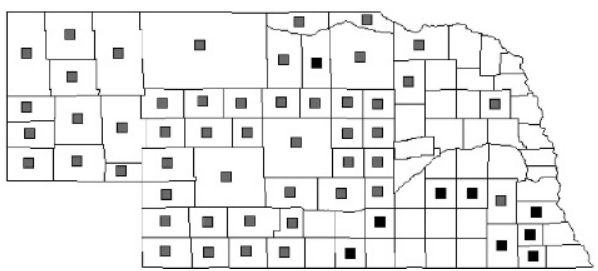

Melanoplus lakinus (Scudder)

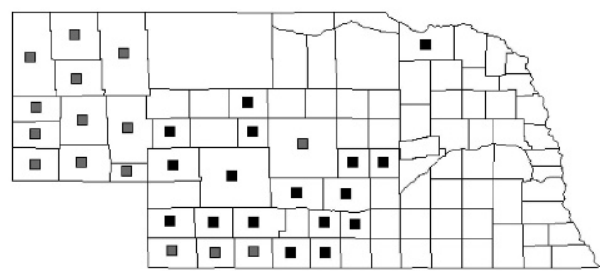

Melanoplus packardii Scudder

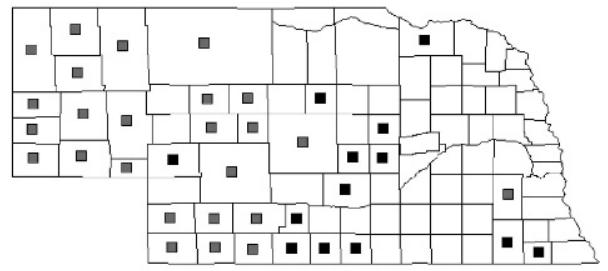

Melanoplus sanguinipes (Fabricius)

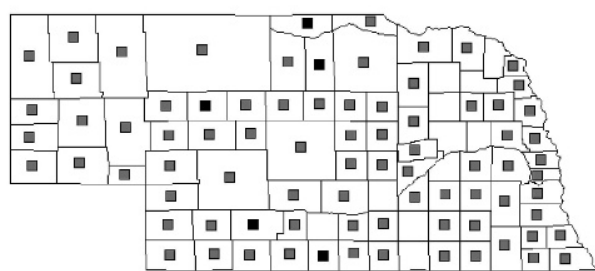

Melanoplus walshii Scudder

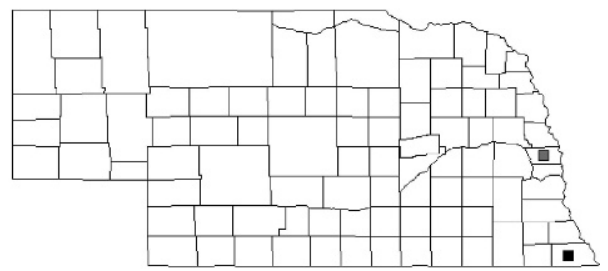

Mermiria picta (Walker)

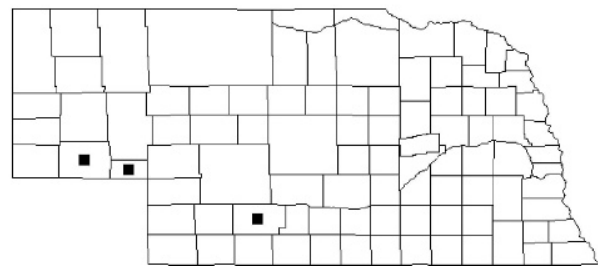

Figs. 3-13. Continued. 
Mestobregma plattei (Thomas)

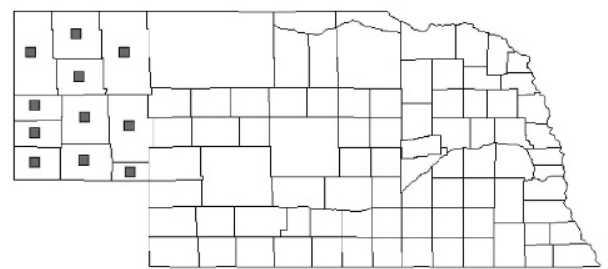

Opeia obscura (Thomas)

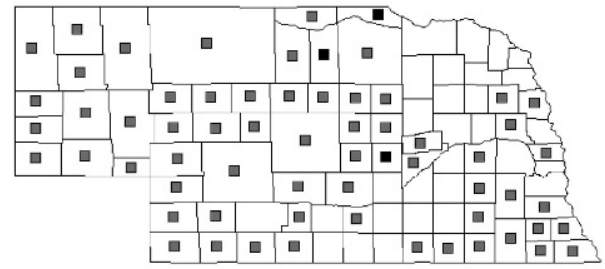

Orphulella speciosa (Scudder)

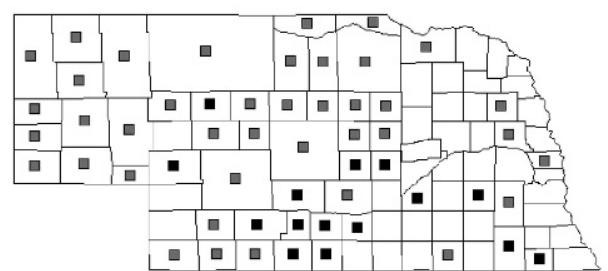

Pardalophora apiculata (Harris)

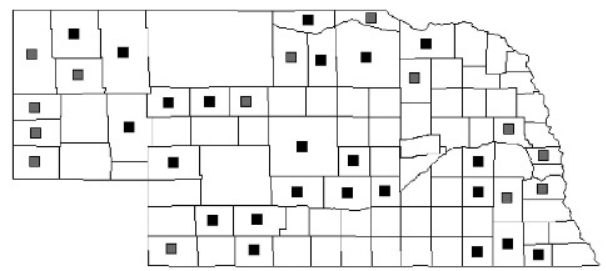

Paropomala wyomingensis (Thomas)

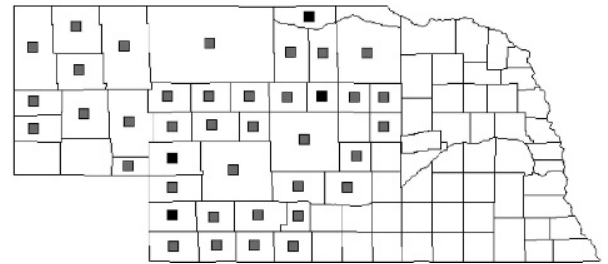

Metator pardalinus (Saussure)

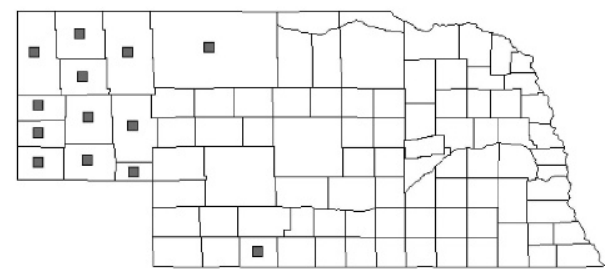

Orphulella pelidna (Burmeister)

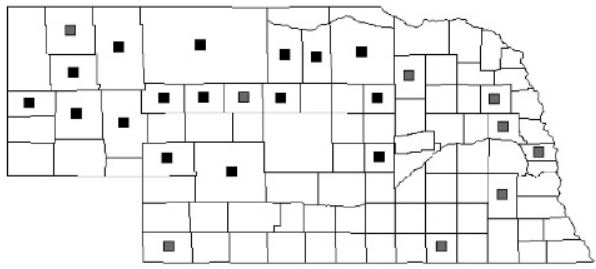

Paratylotropidia brunneri Scudder (new state record)

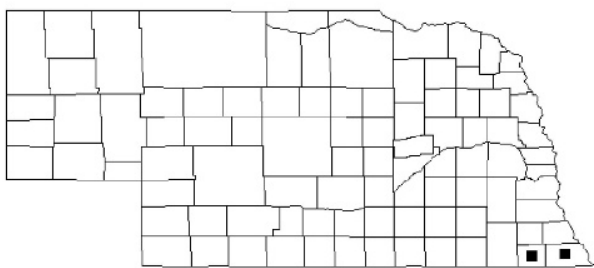

Pardalophora haldemani (Scudder)

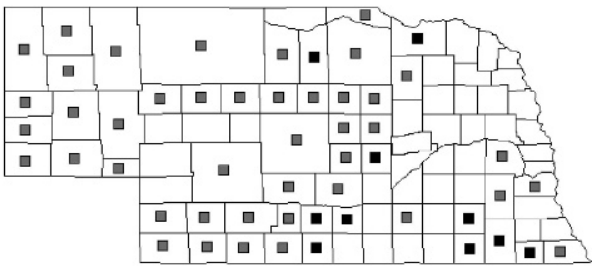

Phlibostroma quadrimaculatum (Thomas)

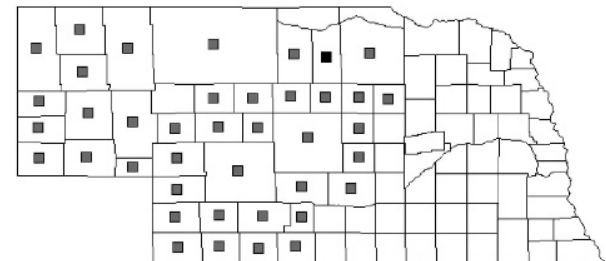

Figs. 3-13. Continued. 
Phoetaliotes nebrascensis (Thomas)

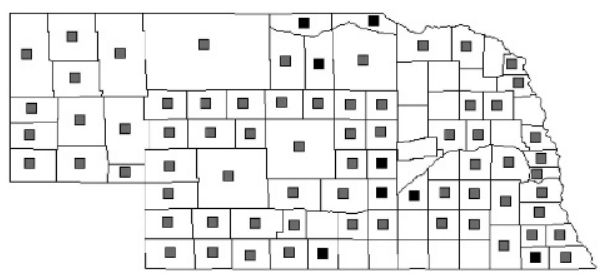

Psinidia fenestralis (Serville)

(new state record)

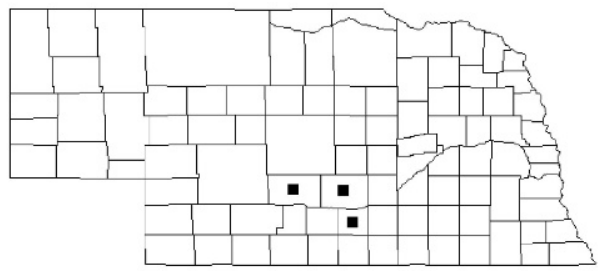

Psoloessa texana Scudder

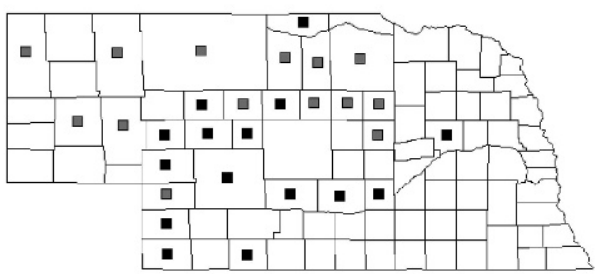

Schistocerca lineata Scudder

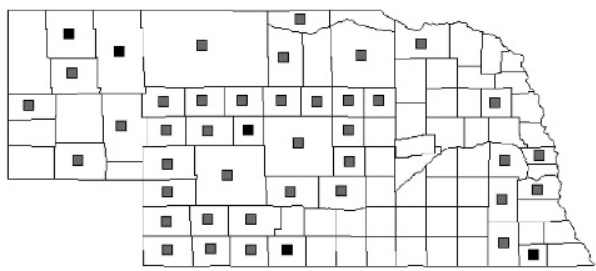

Spharagemon bolli Scudder

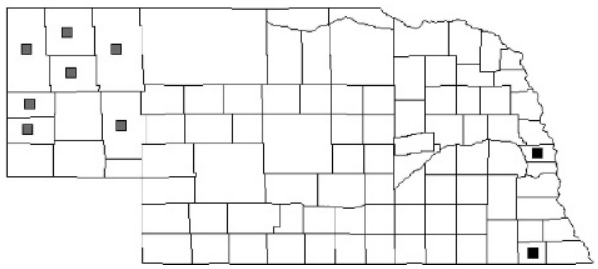

Pseudopomala brachyptera (Scudder)

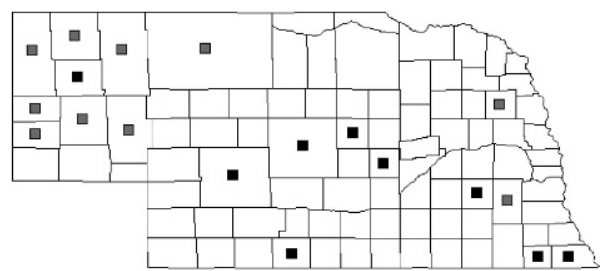

Psoloessa delicatula (Scudder)

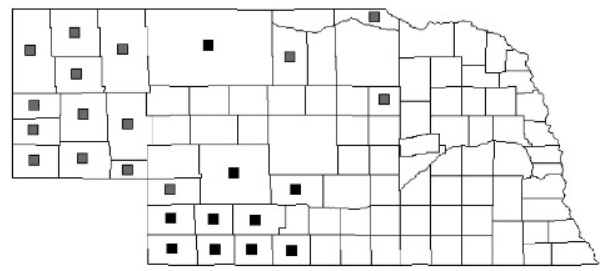

Schistocerca americana (Drury)

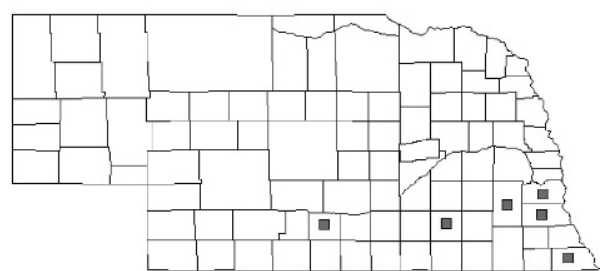

Schistocerca obscura (Fabricius)

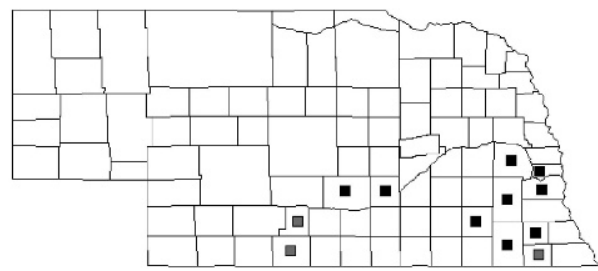

Spharagemon campestris (McNeill)

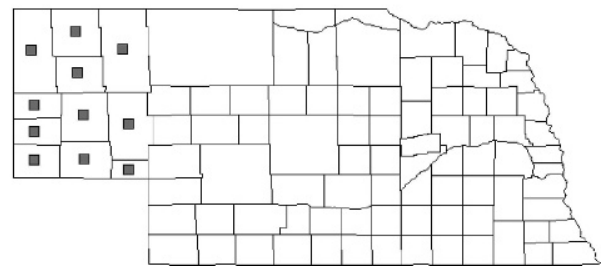

Figs. 3-13. Continued. 
Spharagemon collare (Scudder)

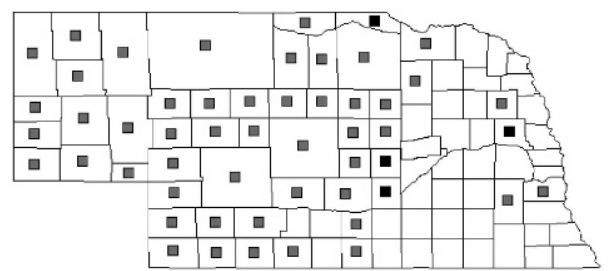

Stethophyma celata Otte

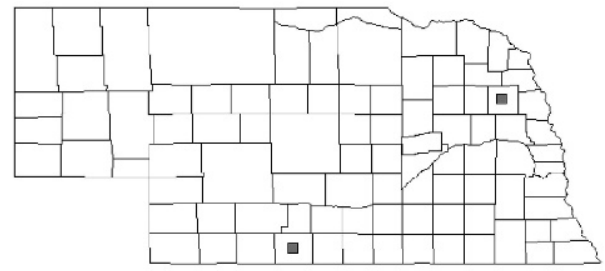

Trachyrhachys aspersa Scudder

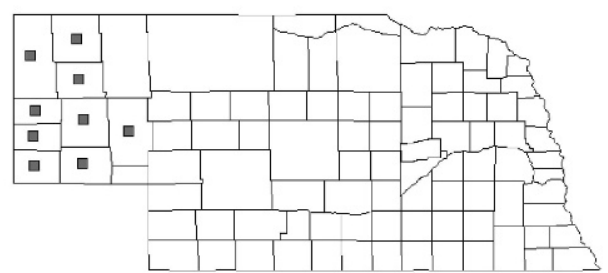

Trimerotropis agrestis McNeill

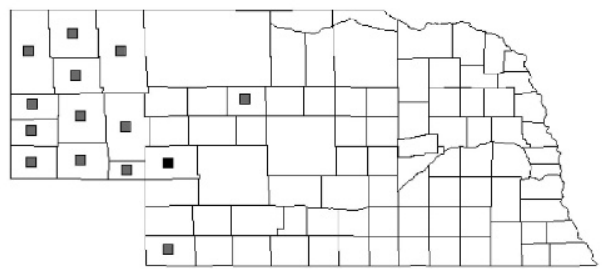

Trimerotropis fratercula $\mathrm{McNeill}$

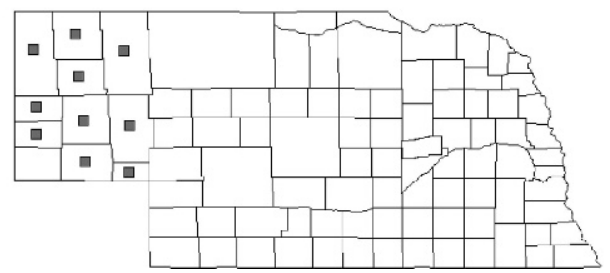

Spharagemon equale (Say)

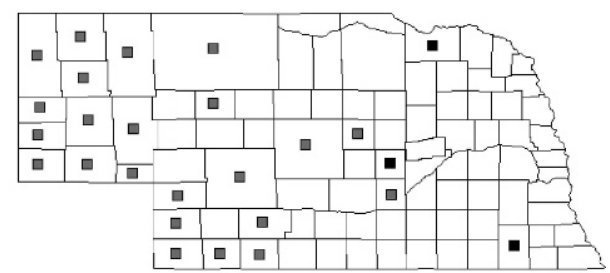

Syrbula admirabilis Uhler

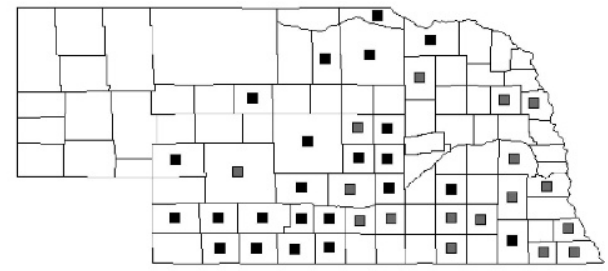

Trachyrhachys kiowa (Thomas)

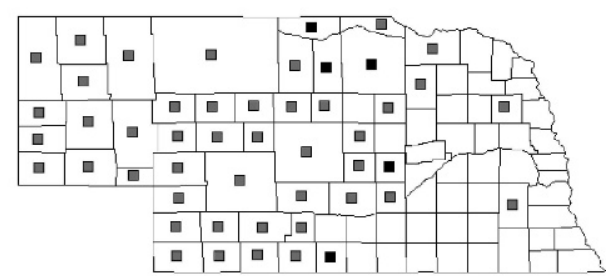

Trimerotropis cincta (Thomas)

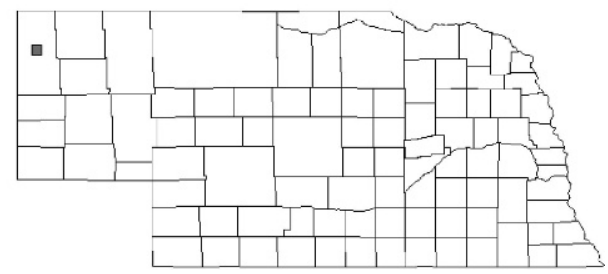

Trimerotropis latifasciata Scudder

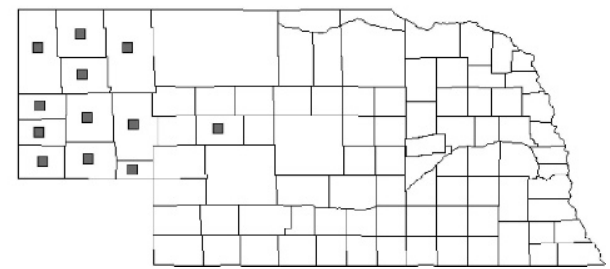

Figs. 3-13. Continued. 
Trimerotropis maritima (Harris)

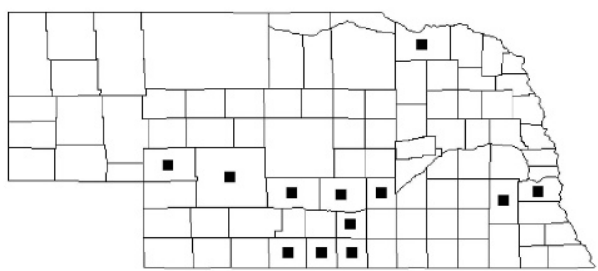

Trimerotropis pistrinaria Saussure

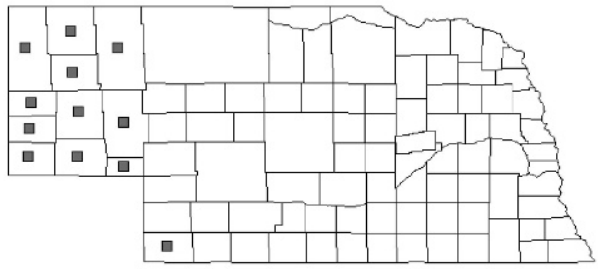

Trimerotropis sparsa (Thomas)

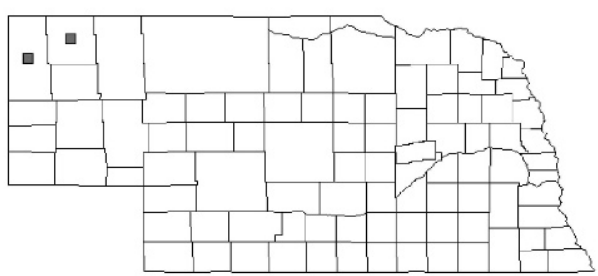

Xanthippus corallipes (Haldeman)

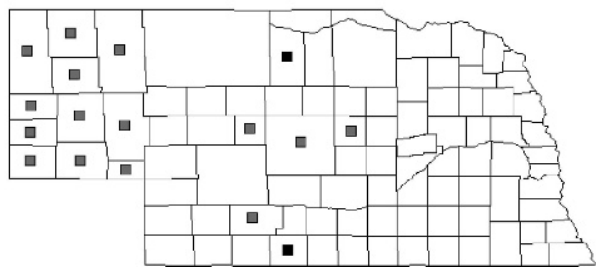

Trimerotropis pallidipennis (Burmeister)

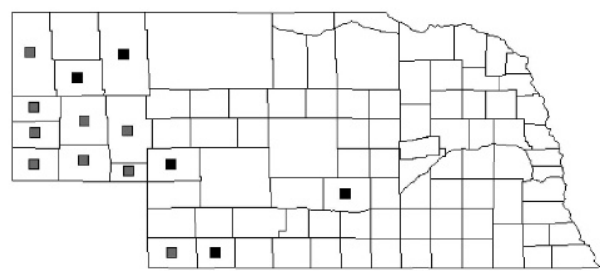

Trimerotropis salina McNeill

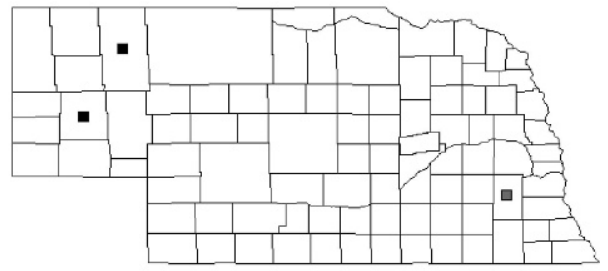

Tropidolophus formosus (Say)

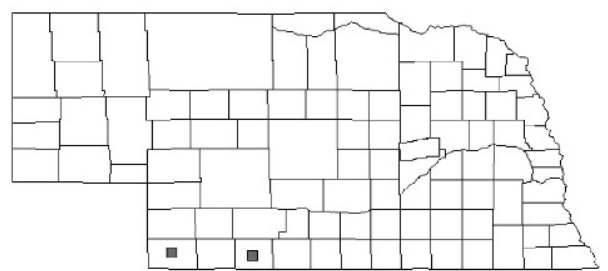

Xanthippus montanus (Thomas)

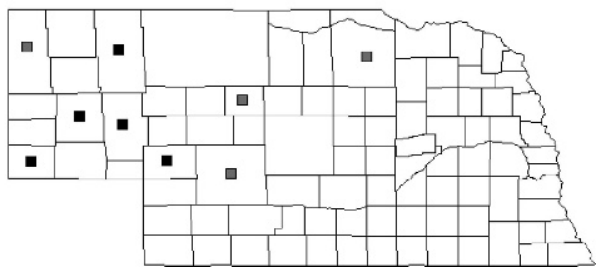

Figs. 3-13. Continued.

this species. We suspect that it might represent a clinal extreme of a highly variable species, with similar phenotypes occurring elsewhere. Alternatively, it might represent a cryptic species that is correctly recognized and shares numerous traits with summer active individuals of $C$. viridifasciata, such as blue tibiae and heavily patterned tegmina. Future work on this group across the entire United States is warranted.

\section{Acknowledgments}

We would like to thank numerous collectors who contributed specimens for this study. These individuals include Brett Morgan (University of Nebraska-Lincoln), Steve Spomer (University of Nebraska-Lincoln), and Jessica Jurzenski (University of Nebraska at Kearney), as well as USDA-APHIS-PPQ grasshopper surveyors from 2005 to 2007 . While most of these individuals were unaware of the identity of the 
specimens they collected, their contributions were greatly appreciated. We also owe thanks to USDA-APHIS for funding this project. We also give thanks to Brett Ratcliffe at the University of Nebraska State Museum who reviewed an earlier version of this manuscript. This is publication \# 1288 from the Department of Entomology.

\section{Literature Cited}

Bailey, R. G. 1995. Description of the ecoregions of the United States. 2nd ed., USDA-Forest Service Miscellaneous Publication 1931, Washington, D.C. 108 pp.

Blatchley, W. S. 1920. Orthoptera of Northeastern America, with especial reference to the faunas of Indiana and Florida. The Nature Publishing Company, Indianapolis, IN. 784 pp.

Bruner, L. 1893. A list of Nebraska Orthoptera. Nebraska Academy of Science Publications 3:19-33.

Bruner, L. 1897. The grasshoppers that occur in Nebraska. Annual Report Entomology, Nebraska State Building of Agriculture, 1897, 105-138.

Capinera, J. L., and T. S. Sechrist. 1982. Grasshoppers (Acrididae) of Colorado: identification, biology, and management. Colorado State University Experiment Station Bulletin 584S:1-161.

Capinera, J. L., R. D. Scott, and T. J. Walker. 2004. Field Guide to grasshoppers, katydids, and crickets of the United States. Cornell University Press, Ithaca, N.Y. 249 pp.

Coppock, S., Jr. 1962. The grasshoppers of Oklahoma. Oklahoma State University Agriculture Experiment Station Bulletin, Processed Series P-399:1-141.

Dodge, G. M. 1876. New species of Acridini from Nebraska. Canadian Entomologist 8:9-12.

Froeschner, R. C. 1954. The grasshoppers and other Orthoptera of Iowa. Iowa State College of Science 29:163-354.

Hagen, A. F. 1970. An annotated list of grasshoppers (Orthoptera: Acrididae) from the eleven panhandle counties of Nebraska. University of Nebraska Resource Bulletin 238:1-60.

Hagen, A. F. 1982. Variations in the wing band of Trimerotropis sparsa (Thomas) (Orthoptera: Acrididae: Oedipodinae). Journal of the Kansas Entomological Society 55:477-480.

Hagen, A. F., and G. G. Rabe. 1991. Distribution maps of grasshopper species in Nebraska based on three studies. Institute of Agriculture and Natural Resources, University of Nebraska-Lincoln. Report No. 16:1-52.

Hauke, H. A. 1953. An annotated list of the Orthoptera of Nebraska, Part II, The Tettigidae and Acrididae. Bulletin of the University of Nebraska State Museum 3:1-79.

Hebard, M. 1925. The Orthoptera of South Dakota. Proceedings of the Academy of Natural Sciences, Philadelphia 77:35-155.

Hebard, M. 1928. The Orthoptera of Montana. Proceedings of the Academy of Natural Sciences, Philadelphia 80:211-306.

Hebard, M. 1929. The Orthoptera of Colorado. Proceedings of the Academy of Natural Sciences, Philadelphia 81:303-425.

Hebard, M. 1931. The Orthoptera of Kansas. Proceedings of the Academy of Natural Sciences, Philadelphia 83:119-227.

Hebard, M. 1932. The Orthoptera of Minnesota. University of Minnesota Agriculture Experiment Station Bulletin 84:1-61.

Hebard, M. 1934. The Dermaptera and Orthoptera of Illinois. Illinois Natural History Survey Bulletin 20:125-279.

Hebard, M. 1936(a). Orthoptera of North Dakota. North Dakota Agriculture Experiment Station Bulletin 284:1-69.

Hebard, M. 1936(b). New genera and species of the Melanopli found within the United States and Canada. Transactions of the American Entomological Society 62:167-187.

Helfer, J. R. 1987. How to Know the Grasshoppers, Crickets, Cockroaches and Their Allies. Dover Publications Inc, New York, N.Y. 363 pp.

Isley, F. B. 1937. Seasonal succession, soil relations, number, and regional distribution of northeastern Texas acridians. Ecological Monographs 7:317-344.

Johnson, W. C. 1994. Woodland expansions in the Platte River, Nebraska: Patterns and causes. Ecological Monographs 64:45-84. 
Kirk, K., and C. R. Bomar. 2005. Guide to the grasshoppers of Wisconsin. Bureau of Integrated Science Services, Wisconsin Department of Natural Resources, Madison, WI. 154 pp.

La Rivers, I. 1948. A synopsis of Nevada Orthoptera. American Midland Naturalist 39:652-720.

Lockwood, J. L. 2004. Locust: The Devastating Rise and Mysterious Disappearance of the Insect that Shaped the American Frontier. Basic Books, New York, N.Y. 294 pp.

Lockwood, J. L., T. J. McNary, J. C. Larsen, and J. Cole. 1993. Distribution atlas for grasshoppers and the Mormon cricket in Wyoming 1988-1992. University of Wyoming Agriculture Experiment Station Bulletin $B-976,117$.

McDaniel, B. 1987. Grasshoppers of South Dakota. South Dakota Agriculture Experiment Station Publication TB 89:1-163.

Mulkern, G. B., K. P. Pruess, H. Knutson, A. F. Hagen, J. B. Campbell, and J. D. Lambley. 1969. Food habits and preferences of grassland grasshoppers of the north central Great Plains. North Dakota Agricultural Experiment Field Station, North Central Regional Publication No. 196, 1-32.

Nerney, N. J. 1960. Grasshopper damage on shortgrass rangeland of the San Carlos Apache Indian Reservation, Arizona. Journal of Economic Entomology 53:640-646.

Omernik, J. M. 1987. Ecoregions of the conternious United States. Map (Scale 1:7,500,000). Annals of the Association of American Geographers 77:118-125.

Omernik, J. M. 1995. Ecoregions: A spatial framework for environmental management. In W. S. Davis and T. P. Simon (eds.). Biological Assessment and Criteria: Tools for Water Resources Planning and Decision Making, pp. 49-62. Lewis Publishers, Boca Raton, FL.

Otte, D. 1981. The North American grasshoppers, Volume I, Acrididae: Gomphocerinae and Acridinae. Harvard University Press, Cambridge, MA. 368 pp.

Otte, D. 1984. The North American Grasshoppers, Volume II, Acrididae: Oedipodinae. Harvard University Press, Cambridge, MA. 366 pp.

Pfadt, R. E. 2002. A field guide to common western grasshoppers. 3rd edition. Wyoming Agricultural Experiment Station. Bulletin 912:1-288.

Schell, S., J. Lockwood, S. Schell, and K. Zimmerman. 2008. Distribution Atlas for Grasshoppers and the Mormon Cricket in Wyoming. http://www.wygisc.uwyo.edu/grasshopper/ghwywfrm.htm. [Last accessed 15 May 2008].

Scudder, S. H. 1897. Revision of the Melanopli. Proceedings of the United States National Museum 20:1-26.

Song, H. 2004. Revision of the Alutacea group of the genus Schistocerca (Orthoptera: Acrididae: Cyrtacanthacridinae). Annals of the Entomological Society of America 97:420-436.

\section{APPENDIX AND SPECIES ACCOUNTS}

\section{New County and State Records for Nebraska and References to Older Records}

This listing only includes new voucher specimens representing county records. A listing of all specimens examined would be excessive. Also included is the number of Nebraska specimens in the collection at USDA-APHIS in Lincoln, Nebraska.

\section{Cyrtacanthacridinae}

\section{Schistocerca americana (Drury)}

Recent collections in Nebraska include only two specimens, both collected in Cass County in 2007. It is a southern species that is known to migrate northward frequently. It is highly unlikely that it breeds in Nebraska.

PREVIOUS RECORDS: Hauke 1953.

Nebraska specimens in USDA collection: 2

\section{Schistocerca lineata Scudder}

This species occurs across most of the state in grasslands. It is highly variable in appearance, and the various forms have previously been assigned to different species. Song (2004) has done a great deal of work on the genus Schistocerca and assigns all 
material from Nebraska to $S$. lineata. Unusually large specimens from the southeastern part of the state resemble $S$. alutacea, but identification by Song has determined them as $S$. lineata. Peak numbers occur from mid-July to early September.

PREVIOUS RECORDS: Hauke 1953, Hagen 1970, Hagen and Rabe 1991.

SPECIMENS EXAMINED: Dawes County, July 19, 2005, (D.A. Widhalm), 1 nymph, Furnas County, September 3, 2007, (M.L. Brust), 1ð̄, Logan County, August 8, 2005, (S.M. Jensen), 1ð̊, 1ơ, Pawnee County, August 12, 2006, (M.L. Brust), 1o, Sheridan County, August 16, 2006, (D.A. Widhalm), 1 \%.

Nebraska specimens in USDA collection: 81

\section{Schistocerca obscura (Fabricius)}

This beautiful grasshopper has been found mostly in the southeastern part of Nebraska, but it ranges west to at least Furnas County. It is most commonly encountered in brushy areas, especially where young elms are abundant. Peak numbers occur from late July to mid-September.

PREVIOUS RECORDS: Hauke 1953.

SPECIMENS EXAMINED: Buffalo County, September 11, 2005, (M.L. Brust), 1へર, 3o, Cass County, July 17, 2007, (C. Reiss; 4-H), 1o, Gage County, September 24, 2002, (R. Jones), 1o, Hall County, August 2, 2007, (J. Scholz; 4-H), 1Q, Johnson County, July 24, 2006, (B. Deoden; 4-H),1, Lancaster County, September 15, 2004, (J.D. Ritter), 1q, Saline County, September 5, 2007, (B. Jackson; 4-H), 1o, Sarpy County, July 24, 2006, (R.J. Anderson), 1Q, Saunders County, July 29, 2007, (M.L. Brust), 10 .

Nebraska specimens in USDA collection: 30

\section{Gomphocerinae}

\section{Acrolophitus hirtipes (Say)}

This species occurs in shortgrass habitats across the western half of Nebraska. It is seldom common and its distribution is spotty. It feeds primarily on low-growing species in the Boraginaceae. Peak numbers occur from late June to mid-August.

PREVIOUS RECORDS: Hauke 1953, Mulkern et al. 1969, Hagen 1970, Hagen and Rabe 1991.

SPECIMENS EXAMINED: Grant County, August 3, 2006, (S.M. Jensen), 1q, Holt County, July 6, 2005, (M.L. Brust), 1o, Logan County, August 16, 2007, (M.L. Brust, 1@, Rock County, July 26, 2006, (R.L. Soles), 1 \%.

Nebraska specimens in USDA collection: 50

\section{Aeropedellus clavatus (Thomas)}

This grasshopper is found across the western two-thirds of Nebraska, but primarily in the northern half. It occurs in low areas such as swales and the edges of marshes. The Lincoln County record, from Whitehorse Creek, represents the southernmost record for the state. Peak numbers occur from late May to mid-July.

PREVIOUS RECORDS: Hauke 1953, Hagen 1970, Hagen and Rabe 1991.

SPECIMENS EXAMINED: Arthur County, June 7, 2005, (S.M. Jensen), 1ㅅ, Banner County, June 15, 2007, (D.A. Widhalm), 10, Blaine County, July 18, 2005, (R.L. Soles), 1o, Box Butte County, June 1, 2006, (D.A. Widhalm), 2o, Cherry County, June 7, 2005, (M.L. Brust), 3ðै, 2Q, Custer County, July 18, 2006, 
(S.Whipple), 1o, Grant County, June 22, 2006, (M.L. Brust), 3̂ै, 3o, Holt County,

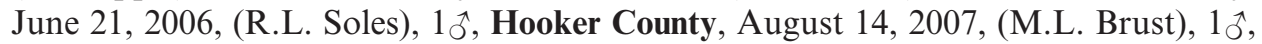
Lincoln County, July 11, 2007 (M.L. Brust), 2o, July 12, 2007 (M.L. Brust), 30ิ, Sheridan County, July 20, 2005, (M.L. Brust), 10ึ.

Nebraska specimens in USDA collection: 183

\section{Ageneotettix deorum (Scudder)}

This destructive range occurs across all of Nebraska. It may be found virtually anywhere that bare soil patches are common in grasslands. While it can be found on a variety of soil types, highest densities typically occur on sandy soils. In the rangeland of the western half of the state, it is the most economically important species. Peak numbers occur from early July to mid-August.

PREVIOUS RECORDS: Hauke 1953, Hagen 1970, Hagen and Rabe 1991.

SPECIMENS EXAMINED: Franklin County, July 21, 2005, (M.L. Brust), 1へ^, 2o, Gage County, July 4, 2006, (M.L. Brust), 1今̂, Howard County, July 18, 2005, (F.L.

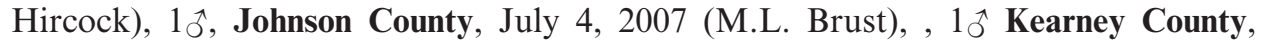
September 10, 2005, (M.L. Brust),1 §, Nance County, October 8, 2005, (M.L. Brust), 1o, Pawnee County, July 2, 2005, (M.L. Brust), 1ðै, Richardson County, July 2, 2005, (M.L. Brust), 10 .

Nebraska specimens in USDA collection: 687

\section{Amphitornus coloradus (Thomas)}

This distinctive species occurs across the western two-thirds of Nebraska. It occurs on a variety of soil types, but prefers areas with an abundance of blue grama (Bouteloua gracilis (Willd. ex. Kunth (Lag. ex. Griffiths)). Peak numbers occur from late June to mid-August.

PREVIOUS RECORDS: Hauke 1953, Hagen 1970, Hagen and Rabe 1991.

SPECIMENS EXAMINED: Custer County, July 31, 2007, (G. Kluch), 10ิ, Dawson County, June 27, 2005, (F.L. Hircock), 1今̋, Frontier County, July 27, 2005, (G.L. Thorson), $1 \delta^{\jmath}$.

Nebraska specimens in USDA collection: 187

\section{Aulocara elliotti (Thomas)}

While there are old records from the eastern parts of Nebraska, this species now appears limited to the western half of the state. The easternmost recent record was from Keith County. It is known to be destructive to rangeland, but has been comparatively uncommon in most of Nebraska in recent years except in limited areas. It prefers shortgrass rangeland. Peak numbers occur from late June to midAugust.

PREVIOUS RECORDS: Hauke 1953, Hagen 1970.

SPECIMENS EXAMINED: Frontier County, June 25, 2007, (G.L. Thorson), 1@, Keith County, June 22, 2006, (M.L. Brust), 1 \%.

Nebraska specimens in USDA collection: 68

\section{Aulocara femoratum Scudder}

This grasshopper is similar to A. elliotti, but the banding on the outer hind femur is distinct. It appears limited to the western half of Nebraska in shortgrass habitats. It is usually less common then $A$. elliotti. Peak numbers occur from late June to mid-August. 
PREVIOUS RECORDS: Hauke 1953, Hagen 1970.

SPECIMENS EXAMINED: Chase County, August 17, 2005, (G.L. Thorson), 1ㅅ, 1o, Hayes County, July 25, 2006, (G.L. Thorson), 1今ึ, Hitchcock County, July 18, 2005, (G.L. Thorson), $1 \hat{\jmath}$.

Nebraska specimens in USDA collection: 40

\section{Boopedon auriventris McNeill}

This grasshopper is only known from two eastern Nebraska Counties. The most recent record was collected from a vacant lot near Omaha. It is suspected that its preferred habitat is oak savanna. Adults have been collected in late summer.

PREVIOUS RECORDS: Hauke 1953.

SPECIMENS EXAMINED: Sarpy County, September 30, 2006, (B. Morgan), 10^. Nebraska specimens in USDA collection: 1

\section{* Boopedon gracile Rehn}

This species is currently recognized as new to Nebraska, but it was first collected in the state in 1932. Specimens from Nuckolls and Thayer Counties were previously called Boopedon maculatum by Hauke (1953). This name was later synonymized with B. nubilum and in Hagen and Rabe (1991), these records were placed as B. nubilum. Recent examination of the specimens shows that they are unquestionably $B$. gracile. This species has now been collected from several additional sites in tallgrass prairie at locations generally within $40 \mathrm{~km}$ of the Kansas border. Peak numbers occur from mid-July to late August.

SPECIMENS EXAMINED: Franklin County, July 21, 2005, (M.L. Brust), 1ðぇ, Gage County, July 22, 2006, (M.L. Brust), 1ð̊, Nuckolls County, July 27, 1932, (H.C.

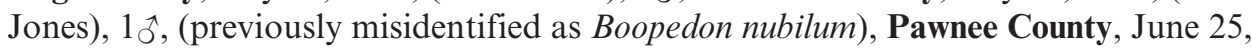
2005, (M.L. Brust), 3 nymphs, Richardson County, July 4, 2006, (M.L. Brust), 1Q, Thayer County, August 9, 1949, (H.A. Hauke), 1ðَ (previously misidentified as Boopedon nubilum). NEW STATE RECORD.

Nebraska specimens in USDA collection: 47

\section{Boopedon nubilim (Say)}

This grasshopper occurs in the western half of Nebraska. This males are almost entirely black, while the females resemble those of other Boopedon species. Females are normally light brown with darker markings and brachypterous. Black females occur occasionally as well as long-winged forms. It is found in shortgrass rangeland and can be locally abundant. It has not been recognized as range-destructive in Nebraska as it has been elsewhere in its range (Nerney, 1960), but localized outbreaks are expected to occur. Peak numbers occur from early July to late August.

PREVIOUS RECORDS: Hauke 1953, Hagen 1970, Hagen and Rabe 1991. *Previous records for Nuckolls and Thayer Counties were misidentified and have reassigned to Boopedon gracile.

Nebraska specimens in USDA collection: 129

\section{Bruneria brunnea (Thomas)}

Bruner (1897) reported this species as extending eastward nearly to middle Nebraska. Hebard (1928) mentioned its collection in western Nebraska, but Hauke (1953) stated that no specimens existed in the collection of the Nebraska State 
Museum. In 2007 a series of seven specimens were collected near the top of Monroe Canyon in Sioux County. Based on discrepancies in the previous literature and lack of specimens in collections, this species could be considered new to the state.

PREVIOUS RECORDS: Bruner 1897, Hebard 1928, Hauke 1953.

SPECIMENS EXAMINED: Sioux County, July 26, 2006, (M.L. Brust), 4ð̊, 3 o.

Nebraska specimens in USDA collection: 7

\section{* Chloealtis abdominalis (Thomas)}

The single specimen in the Nebraska State Museum collection represents a significant southward extension for this species. This collecting data for this specimen are potentially erroneous, or that this species occurred in a unique microhabitat near the Niobrara River.

SPECIMENS EXAMINED: Knox County, August 2, 1902, (W.D. Pierce), 1ðै, NEW STATE RECORD.

Nebraska specimens in USDA collection: 0

\section{Chloealtis conspersa (Harris)}

This species occurs in scattered populations throughout Nebraska. It prefers wooded habitats, and most Nebraska records have been from along the Platte and Missouri Rivers. It can be attracted to light and a single male was collected at a mercury vapor lamp in Nemaha County in 2006. Peak numbers occur from mid-June to mid-July.

PREVIOUS RECORDS: Hauke 1953, Hagen 1970, Hagen and Rabe 1991.

SPECIMENS EXAMINED: Buffalo County, July 1, 2006, (M.L. Brust), 2o, Dawson County, July 10, 2007, (M.L. Brust), 2o, Nemaha County, July 18, 2006 (S.M. Spomer), 1o, Richardson County, August 12, 2006, (M.L. Brust), 2Q.

Nebraska specimens in USDA collection: 38

\section{Chorthippus curtipennis (Harris)}

This species is scattered across the whole of Nebraska but is more prevalent toward the north. It prefers low areas such as marshes, meadows and low swales. Peak numbers occur from mid-June to late July.

PREVIOUS RECORDS: Hauke 1953, Mulkern et al. 1969, Hagen 1970, Hagen and Rabe 1991.

SPECIMENS EXAMINED: Grant County, July 20, 2005, (M.L. Brust), 2o, Holt County, August 3, 2005, (R.L. Soles), 2Q, Hooker County, (M. Giovanni, L. ThackerLynne, L. Anderson), 1へै, Pierce County, August 10, 2007, (S. Whipple), 1 o.

Nebraska specimens in USDA collection: 39

\section{Cordillacris crenulata (Bruner)}

This is a small and scarce species in Nebraska, although known to be rangedestructive in other states to the west. It appears to only enter the western edges of the state. It appears to breed in localized areas as a series of eight individuals was obtained from a sweep sample from Sioux County in 2006. Peak numbers occur from mid-June to late July.

PREVIOUS RECORDS: Hauke 1953, Hagen and Rabe 1991. 
SPECIMENS EXAMINED: Hayes County, July 19, 2005, (G.L. Thorson), 10, Hitchcock County, July 18, 2005, (G.L. Thorson), 1o, Sioux County, July 17, 2006, (D.A. Widhalm), 5ㅅ, 3ㅇ․

Nebraska specimens in USDA collection: 15

\section{Cordillacris occipitalis (Thomas)}

This is a common species in sandy and loamy areas across the western two-thirds of Nebraska. It can occasionally reach economically damaging levels. Peak numbers occur from mid-June to late July.

PREVIOUS RECORDS: Hauke 1953, Mulkern et al. 1969, Hagen 1970, Hagen and Rabe 1991.

Nebraska specimens in USDA collection: 181

\section{Dichromorpha viridis (Scudder)}

This is a common grasshopper in open woodland in the southeastern United States. In Nebraska it is limited to low moist areas. It is abundant near Salt Creek in Lincoln, and occurs across most of the state along streams and in roadside ditches. Adults have two color phases, green or brown. Long-winged females may occur rarely, but long-winged males have not been found in Nebraska.

PREVIOUS RECORDS: Hauke 1953, Hagen and Rabe 1991.

SPECIMENS EXAMINED: Antelope County, August 10, 2007, (S. Whipple), 2ð, Brown County, August 12, 2007, (S. Whipple), 1ð̊, Gosper County, July 23, 2007, (G. Kluch), 1§̂, Greeley County, August 16, 2007, (G. Kluch), 1o, Holt County, August 6, 2007, (R.L. Soles), 3^^, Johnson County, July 15, 2007, (A. Bauer; 4-H), 1o, Kearney County, September 10, 2005, (M.L. Brust), 1o, Nemaha County, August 12, 2006, (M.L. Brust), 1Q, Pawnee County, July 22, 2006, (M.L. Brust), 1o, Rock County, August 1, 2007, (R.L. Soles), 2̧ै, Sherman County, August 13, 2007, (G. Kluch), 1o, York County, August 13, 2007, (M.L. Brust), 10ิ.

Nebraska specimens in USDA collection: 141

\section{Eritettix simplex (Scudder)}

This springtime species is abundant in grasslands across most of Nebraska. It has likely vanished from many areas across the eastern third of the state as grasslands have been replaced with row crops. It is variable in appearance and easily confused with Opeia obscura. Peak numbers occur from mid-April to mid-June.

PREVIOUS RECORDS: Hauke 1953, Mulkern et al. 1969, Hagen 1970, Hagen and Rabe 1991.

SPECIMENS EXAMINED: Butler County, May 13, 2007, (M.L. Brust), 1o, Gage County, June 24, 2007 (M.L. Brust), 10ิ, Harlan County, June 11, 2005, (F.L.

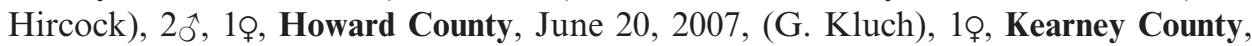

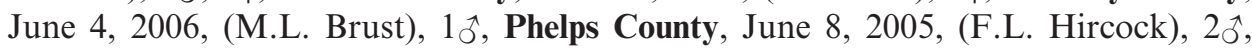
Platte County, April 28, 2007, (M.L. Brust), 1§, Seward County, June 30, 2007, (M.L. Brust), 10ิ.

Nebraska specimens in USDA collection: 403

\section{Heliaula rufa (Scudder)}

This is a scarce species in Nebraska. It has only been collected from four panhandle counties in small series. It is reported to prefer gravelly hillsides with 
sparse vegetation and is seldom numerous. Nebraska records are from July and August.

PREVIOUS RECORDS: Hauke 1953, Hagen 1970.

Nebraska specimens in USDA collection: 0

\section{Mermiria bivittata (Serville)}

This is a common grassland species which occurs throughout Nebraska. Mermiria maculipennis has formerly been considered a separate species, but is now placed as a synonym of $M$. bivittata. Peak numbers occur from mid-July to late August.

PREVIOUS RECORDS: Hauke 1953, Hagen 1970, Hagen and Rabe 1991.

SPECIMENS EXAMINED: Adams County, June 27, 2005, (C. Aubushon; 4-

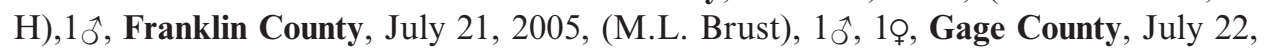

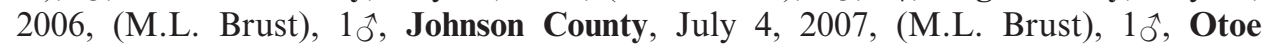
County, August 25, 2007, (M.L. Brust), 1ðَ, Pawnee County, July 23, 2005, (M.L.

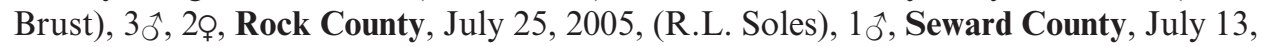
2007, (M.L. Brust), 10ิ, 1o, York County, August 13, 2007, (M.L. Brust), 1 o.

Nebraska specimens in USDA collection: 224

\section{Mermiria picta (Walker)}

This species has formerly been called Mermiria neomexicana Thomas. It is only known for Nebraska from three specimens, two of which were from the southern panhandle. A single female was collected in Fremont County, Iowa, about $10 \mathrm{~km}$ east of Nebraska City in 2005. This suggests that it might also occur on hilltops near the Missouri River in eastern Nebraska. More recently a single specimen was collected in a sweep sample in Frontier County.

SPECIMENS EXAMINED: Cheyenne County, August 31, 1964 (A.F. Hagen),

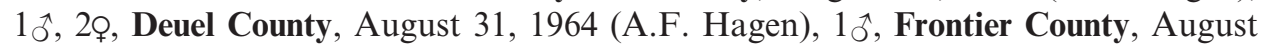
22, 2007, (G.L. Thorson), 1Q.

Nebraska specimens in USDA collection: 1

\section{Opeia obscura (Thomas)}

This grasshopper has been recorded from across most of Nebraska. Its occurrence, especially alongside Phlibostroma quadrimaculatum and Trachyrhachys kiowa, is often indicative of overgrazed rangeland. It is most numerous in shortgrass areas among blue grama (Bouteloua gracilis) and buffalograss (Buchloe dactyloides (L.)). Peak numbers occur from late July to mid-September.

PREVIOUS RECORDS: Hauke 1953, Hagen 1970, Hagen and Rabe 1991.

SPECIMENS EXAMINED: Boyd County, August 9, 2007, (R.L. Soles), 1ô, Howard County, August 11, 2006, (S. Whipple), 1Q, Rock County, July 26, 2005, (R.L. Soles), $3 \widehat{\jmath}, 2$,

Nebraska specimens in USDA collection: 234

\section{Orphulella pelidna (Burmeister)}

This species is similar in appearance to O. speciosa. It differs in having longer wings and two sulci cutting through the lateral carina of the pronotum. It occurs mostly in low meadows, marshes, and swales. It appears to be attracted to lights as a single female was collected at a light at Bridgeport in Morrill County in 2007. Peak numbers occur from late July to mid-September. 
PREVIOUS RECORDS: Hauke 1953.

SPECIMENS EXAMINED: Blaine County, July 18, 2005, (R.L. Soles), 10, Box Butte County, July 12, 2007, (D.A. Widhalm), 1o, Brown County, July 24, 2006, (R.L. Soles), 1o, Cherry County, August 10, 2005, (R.L. Soles), 2o, Garden County, July 20,

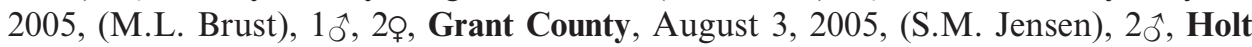
County, August 14, 2006, (R.L. Soles), 2ิૈ, 1o, Hooker County, August 14, 2006,

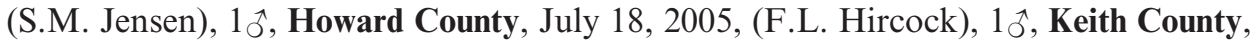
August 15, 2005, (G.L. Thorson), 20ิ, 1क, Lincoln County, July 12, 2007, (M.L. Brust), 2o, Morrill County, July 25, 2006, (M.L. Brust), 2o, Rock County, July 25, 2005, (R.L. Soles), 10َ, 1o, Scotts Bluff County, July 6, 2006, (D.A. Widhalm), 1o, Sheridan County, July 19, 2005, (M.L. Brust), 1今ึ, 1o, Wheeler County, July 26, 2005, (M.L. Brust), 1ð․

Nebraska specimens in USDA collection: 116

\section{Orphulella speciosa (Scudder)}

This is a common rangeland species, especially on heavy soils. It occurs throughout Nebraska but is most numerous on the loess soils in the central part of the state. Peak numbers occur from mid-July to mid-September.

PREVIOUS RECORDS: Hauke 1953, Hagen 1970, Hagen and Rabe 1991.

SPECIMENS EXAMINED: Dawson County, July 29, 2005, (F.L. Hircock), 1ㅅ, Frontier County, July 27, 2005, (G.L. Thorson), 1ో, 1Q, Furnas County, September 7, 2005, (F.L. Hircock), 1§, Gage County, August 12, 2007, (M.L. Brust), 1o, Gosper County, July 23, 2007, (G. Kluch), 2ð, 2o, Hamilton County, July 13, 2007, (M.L. Brust), 1ิึ, Harlan County, July 17, 2007, (G. Kluch), 10ิ, Hooker County, August 11, 2005, (S.M. Jensen), 1o, Howard County, July 19, 2005, (F.L. Hircock), 20ิ, Kearney County, September 10, 2005, (M.L. Brust), 1o, Keith County, August 15, 2005, (G.L. Thorson), 1क, Pawnee County, July 23, 2005, (M.L. Brust), 5ô, 4ᄋ, Phelps County, July 18, 2007, (G. Kluch), 1§ิ, Seward County, July 13, 2007, (M.L. Brust), 10ิ, Sherman County, August 3, 2005, (F.L. Hircock), 1Q.

Nebraska specimens in USDA collection: 263

\section{Paropomala wyomingensis (Thomas)}

This grasshopper is common among bunchgrasses, particularly little bluestem. It is common in mixed-grass rangeland, but becomes more restricted to swales in shortgrass habitats. It has been recorded from most of the western two-thirds of Nebraska. Peak numbers occur from mid-July to late August.

PREVIOUS RECORDS: Hauke 1953, Hagen 1970, Hagen and Rabe 1991.

SPECIMENS EXAMINED: Chase County, August 16, 2005, (G.L. Thorson), 1o,

Keith County, August 11, 2005, (G.L. Thorson), 20, 1ᄋ, Keya Paha County, August 1, 2007, (R.L. Soles), 1o, Loup County, July 18, 2007, (R.L. Soles), 1 \%.

Nebraska specimens in USDA collection: 172

\section{Phlibostroma quadrimaculatum (Thomas)}

This species has been recorded from across most of the western two thirds of Nebraska. It is most common in shortgrass areas and can be common in overgrazed areas. Peak numbers occur from late July to mid-September.

PREVIOUS RECORDS: Hauke 1953, Hagen 1970, Hagen and Rabe 1991.

SPECIMENS EXAMINED: Rock County, July 25, 2005, (R.L. Soles), 4ðَ, 1 \% . 
Nebraska specimens in USDA collection: 133

\section{Pseudopomala brachyptera (Scudder)}

This grasshopper has been collected from scattered locations throughout Nebraska. It is seldom common and is usually found in tall grasses along the edges of wooded areas. Peak numbers occur from mid June to early August.

PREVIOUS RECORDS: Hauke 1953, Hagen 1970.

SPECIMENS EXAMINED: Box Butte County, July 18, 2005, (D.A. Widhalm),

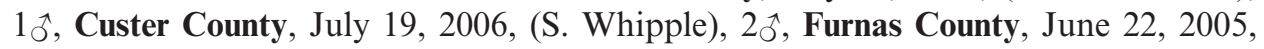

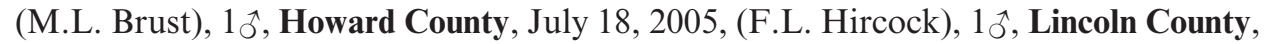

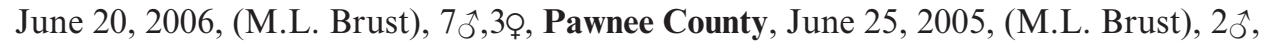
Richardson County, July 4, 2006, (M.L. Brust), 19, Seward County, June 30, 2007, (M.L. Brust), 1§, Valley County, August 13, 2007, (G. Kluch), 1 \%.

Nebraska specimens in USDA collection: 72

\section{Psoloessa delicatula (Scudder)}

This is a common springtime species in shortgrass rangeland. It occurs primarily on heavy soils. Older records indicate it occurs throughout the panhandle and in the northern part of the state, and recent records show that is also occurs on loess soils throughout the southwestern portion of the state. Peak numbers occur from midApril to mid-June.

PREVIOUS RECORDS: Hauke 1953, Hagen 1970, Hagen and Rabe 1991.

SPECIMENS EXAMINED: Chase County, May 18, 2005, (M.L. Brust), 1o, Cherry County, June 7, 2005, (M.L. Brust), 2Q, Dawson County, June 7, 2005, (F.L.

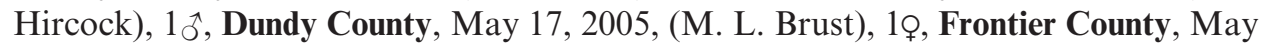

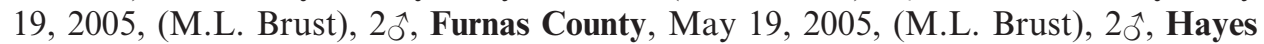
County, May 18, 2005, (M.L. Brust), 2o, Hitchcock County, May 18, 2005, (M.L. Brust), 4کิ,6९, Lincoln County, June 4, 2007, (G.L. Thorson), 1o, Red Willow County, May 19, 2005, (M.L. Brust), 1 \%.

Nebraska specimens in USDA collection: 196

\section{Psoloessa texana Scudder}

This species occurs across much of the state in sandy areas and most common in dry sandy areas that are sparsely vegetated. It is seldom found alongside the preceding species. Peak numbers occur from early April to early June.

PREVIOUS RECORDS: Hauke 1953, Hagen and Rabe 1991.

SPECIMENS EXAMINED: Arthur County, May 22, 2006, (S.M. Jensen), 10, Blaine County, June 6, 2005, (M.L. Brust), 1ðَ, Buffalo County, June 4, 2006, (M.L. Brust), 4o, Chase County, May 18, 2005, (M.L. Brust), 2@, Dawson County, June 19, 2006, (M.L. Brust), 1థ, Dundy County, May 17, 2005, (M.L. Brust), 2§ิ,4ㅇ, Furnas County, May 19, 2005, (M.L. Brust), 1َ̧, Hall County, April 28, 2007, (M.L. Brust), 1\%, Hooker County, June 7, 2005, (M.L. Brust), 1Q, Keith County, May 25, 2006,

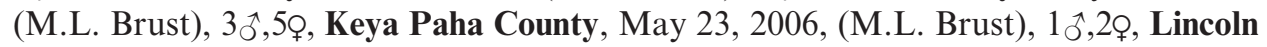
County, May 9, 2005, (M.L. Brust), 5o, Logan County, June 2, 2005, (S.M. Jensen), 3ิै, McPherson County, May 24, 2006, (M.L. Brust), 1@, Platte County, April 28, 2007, (M.L. Brust), 1o, Red Willow County, May 19, 2005, (M.L. Brust), 1 ọ.

Nebraska specimens in USDA collection: 187 


\section{Stethophyma celata Otte}

This recently described species is known from only two widely scattered counties in Nebraska. It prefers marshy areas and low meadows.

PREVIOUS RECORDS: Hagen and Rabe 1991.

Nebraska specimens in USDA collection: 0

\section{Syrbula admirabilis Uhler}

This grasshopper has been recorded across the eastern two-thirds of Nebraska as far west as Keith County. It is common in areas with tall grass. In the west it is most common along roadsides and in hayfields. Peak numbers occur from early August to late September.

PREVIOUS RECORDS: Hauke 1953, Hagen and Rabe 1991.

SPECIMENS EXAMINED: Boyd County, August 18, 2005, (R.L. Soles), 20ิ, Chase County, August 9, 2007, (G.L. Thorson), 20, Custer County, August 26, 2005, (F.L. Hircock), 1o, Dawson County, July 31, 2006, (S. Whipple), $1 \hat{\jmath}$, Frontier County, July 27, 2005, (G.L. Thorson), 1 nymph, Furnas County, August 23, 2006, (R.L.

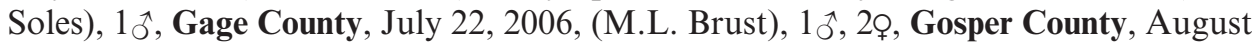
24, 2006, (R.L. Soles), 1o, Greeley County, August 9, 2006, (R.L. Soles), 1ô, Hall County, August 20, 2006, (M.L. Brust), 10ิ, Harlan County, August 22, 2006, (R.L. Soles), 1o, Hayes County, August 2, 2007, (G.L. Thorson), 1今̄, Hitchcock County, August 1, 2007, (G.L. Thorson), 10, Holt County, August 15, 2006, (R.L. Soles), 1o, Howard County, August 10, 2006, (S. Whipple), 1ð̄, Keith County, August 24, 2006,

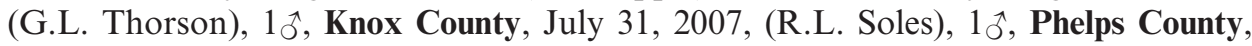
July 27, 2006, (S. Whipple), 1َ̧, Red Willow County, August 1, 2006, (G.L. Thorson), 1ิึ, Rock County, August 11, 2007, (S. Whipple), 1o, Sherman County, August 15, 2006, (S. Whipple), 1o, Thomas County, August 16, 2007, (M.L. Brust), 1o, York County, August 13, 2007, (M.L. Brust), 1ð̊.

Nebraska specimens in USDA collection: 128

\section{Melanoplinae}

\section{Aeoloplides turnbulli (Caudell)}

This species is found mostly in the western third of Nebraska. It can be locally numerous and feeds on members of the Chenopodiaceae. Peak numbers occur from early July to late August.

PREVIOUS RECORDS: Hauke 1953, Mulkern et al. 1969, Hagen 1970, Hagen and Rabe 1991.

SPECIMENS EXAMINED: Arthur County, July 14, 2005, (S.M. Jensen), 10, Chase County, August 9, 2007, (G.L. Thorson), 2^, 4ㅇ, Frontier County, July 31,

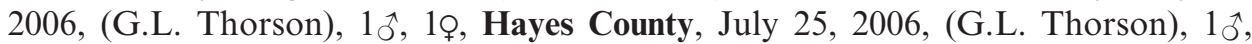
Keith County, June 22, 2006, (M.L. Brust), 1 1 , 30.

Nebraska specimens in USDA collection: 93

\section{Campylacantha olivacea (Scudder)}

This olive-green colored grasshopper is found across much of Nebraska, but appears scarce toward the west. As it feeds on ragweed it could be considered a beneficial species. Most specimens are green in color, but dark gray individuals do occur rarely. Peak numbers occur from late July to mid-September.

PREVIOUS RECORDS: Hauke 1953, Hagen 1970, Hagen and Rabe 1991. 
SPECIMENS EXAMINED: Boyd County, August 21, 2006, (R.L. Soles), 10ิ, Buffalo County, August 27, 2005, (F.L. Hircock), 1o, Dawson County, September 2, 2006, (M.L. Brust), 2o, Furnas County, August 23, 2006, (R.L. Soles), 1o, Gage County, October 7, 2006, (M.L. Brust), 1§̋, Gosper County, August 24, 2006, (R.L.

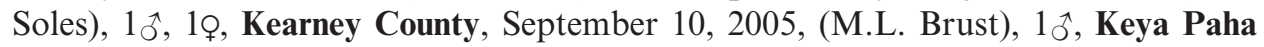
County, August 15, 2005, (R.L. Soles), 1 nymph, Knox County, July 31, 2007, (R.L.

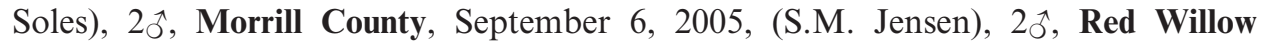
County, August 21, 2007, (G.L. Thorson), 2ð, Thomas County, August 11, 2005, (S.M. Jensen), 20ิ.

Nebraska specimens in USDA collection: 116

\section{Dactylotum bicolor (Thomas)}

This is perhaps the most colorful grasshopper in Nebraska. It has been recorded from much of the state, but has likely been extirpated from most of the eastern third. It is seldom abundant, but can be locally common. Peak numbers occur from midJuly to late August.

PREVIOUS RECORDS: Hauke 1953, Hagen 1970, Hagen and Rabe 1991.

SPECIMENS EXAMINED: Arthur County, August 1, 2006, (S.M. Jensen), 10, Garfield County, July 16, 2007, (R.L. Soles), 1 nymph, Grant County, July 17, 2007, (S.M. Jensen), 1ðै, Hitchcock County, July 20, 2006, (G.L. Thorson), 1Q, Keith County, July 26, 2007, (M.L. Brust), 1o, Logan County, August 16, 2007, (M.L. Brust), 2へิ, Perkins County, August 13, 2007, (G.L. Thorson), $1 \hat{\jmath}$.

Nebraska specimens in USDA collection: 79

\section{Hesperotettix speciosus (Scudder)}

This colorful grasshopper likely occurs throughout Nebraska but has probably been extirpated from much of the eastern third. It appears to prefer areas with abundant sunflower. Peak numbers occur from mid-July to early September.

PREVIOUS RECORDS: Hauke 1953, Hagen 1970, Hagen and Rabe 1991.

SPECIMENS EXAMINED: Brown County, July 20, 2005, (R.L. Soles), 1へર, Hall County, July 1, 2006, (M.L. Brust), $1 \hat{\jmath}$, Harlan County, July 17, 2007, (G. Kluch), 1o, Keya Paha County, August 16, 2005, (R.L. Soles), 1今̄, Rock County, July 25, 2005, (R.L. Soles), 1 ô.

Nebraska specimens in USDA collection: 143

\section{Hesperotettix viridis (Scudder)}

This colorful grasshopper is found throughout Nebraska in a variety of grassland types. It is highly variable in appearance, and numerous subspecies have been named. The validity of many of these subspecies is questionable. H. v. pratensis occurs across the eastern two-thirds of the state, while $H$. v. viridis occurs to the west. However, populations in which all individuals resemble ssp. pratensis have been found in the western half of the panhandle, and casts doubt on the validity of ssp. pratensis. It may consist of more than one species, or it may be highly variable throughout its range. It is considered beneficial as it feeds on snakeweeds (Gutierezia sp.), which are toxic to cattle. Peak number occur from early July to late September.

PREVIOUS RECORDS: Hauke 1953, Hagen 1970, Hagen and Rabe 1991.

SPECIMENS EXAMINED: Arthur County, July 14, 2005, (S.M. Jensen), 1o, Blaine County, July 27, 2005, (M.L. Brust), 1Q, Gage County, June 24, 2007 (M.L. 


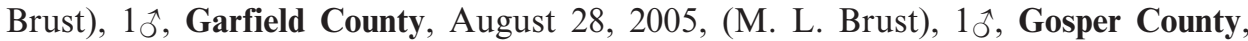
August 24, 2006, (R.L. Soles), 1o, Grant County, July 20, 2005, (M.L. Brust), 1o, Hall County, July 1, 2006, (M.L. Brust), 1, Hitchcock County, August 1, 2007, (G.L. Thorson), 1o, Holt County, July 6, 2005, (M.L. Brust), 1今̋, Howard County, July 29,

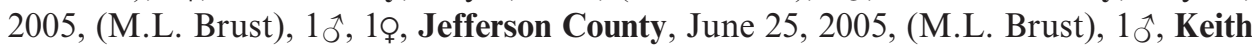
County, July 12, 2005, (M.L. Brust), 1o, Keya Paha County, August 15, 2005, (R.L. Soles), 1o, Loup County, July 30, 2005, (M.L. Brust), 1o, McPherson County, August

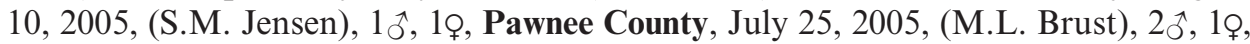
Phelps County, July 26, 2005, (F.L. Hircock), 10َ, Rock County, July 7, 2005, (M.L. Brust), 1ð, 2o, Seward County, June 30, 2007, (M.L. Brust), 10ิ, Thomas County, August 29, 2005, (S.M. Jensen), 1ð̊, Wheeler County, July 26, 2005, (M.L. Brust), 1 Q .

Nebraska specimens in USDA collection: 191

\section{Hypochlora alba (Dodge)}

This cryptic species is colored like its favored hostplant, cudweed sagewort (Artemesia ludoviciana Nutt.). It occurs in grassland throughout Nebraska. It is usually brachypterous, but long-winged females are collected occasionally. Peak numbers occur from early July to late August.

PREVIOUS RECORDS: Dodge 1876, Hauke 1953, Mulkern et al. 1969, Hagen 1970, Hagen and Rabe 1991.

SPECIMENS EXAMINED: Boyd County, August 9, 2007, (R.L. Soles), 10ै, Buffalo County, July 24, 2007, (G. Kluch), 1ð, Garfield County, July 25, 2005, (M.L. Brust), 3今̄, Grant County, July 20, 2005, (M.L. Brust), 1o, Greeley County, August

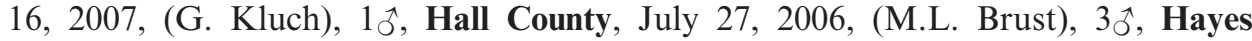
County, July 21, 2005, (G.L. Thorson), 1Q, Holt County, August 7, 2007, (R.L.

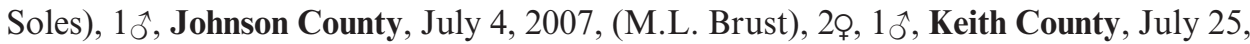
2006, (G.L. Thorson), 1o, Keya Paha County, August 15 , 2005, (R.L. Soles), 2ᄋ, Loup County, July 27, 2005, (M.L. Brust), 1@, McPherson County, August 9, 2005, (S.M. Jensen), 1థ, Rock County, July 26, 2005, (R.L. Soles), 1ðَ, Wheeler County, July 26, 2005, (M.L. Brust), 1 Q.

Nebraska specimens in USDA collection: 160

\section{Melanoplus angustipennis (Dodge)}

This grasshopper is abundant in sandy areas throughout Nebraska and can be excessively abundant in the sandhills. It feeds primarily on forbs and is unlikely to do economic damage, despite its abundance. Peak numbers occur from early July to late August.

PREVIOUS RECORDS: Hauke 1953, Hagen 1970, Hagen and Rabe 1991.

SPECIMENS EXAMINED: Furnas County, September 3, 2007, (M.L. Brust), 1ᄋ, Hall County, July 1, 2006, (M.L. Brust), 1o, Howard County, July 29, 2005, (M.L. Brust), 2๙ิ, 1@, Kearney County, August 18, 2006, (M.L. Brust), 2o, Knox County, July 6, 2005, (M.L. Brust), 1ô, 10.

Nebraska specimens in USDA collection: 661

\section{*Melanoplus bispinosus Scudder}

This species has probably been overlooked. As it was first recorded in Nebraska in 2005 and has since been collected in eight counties. It can be locally common and is usually found in sandy areas near rivers and streams, often alongside Melanoplus 
angustipennis and M. fluviatilis. It is suspected that Hebard (1931) might have been referring to this species when stating that Melanoplus regalis had been collected in Dodge County and the Republican River in Nebraska. Recent collections of $M$. regalis have shown it to range only as close as southwestern Kansas. Melanoplus bispinosus is similar in appearance to $M$. confusus, but is larger, more boldly marked, and occurs later in the season. The male genitatia are also distinct. The nymphs are similar to those of $M$. sanguinipes, but are more boldly marked and exhibit strongly blue tibiae by the last instar. Peak numbers occur from early August to late September.

SPECIMENS EXAMINED: Antelope County, August 10, 2007, (S. Whipple), 1ð, 1Q, Buffalo County, July 1, 2006, (M.L. Brust), 3今ึ, 2o, Dawson County, September 2,

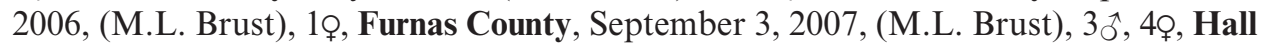
County August 20, 2006, (M.L. Brust), 2Q, Holt County, August 17, 2005, (R.L. Soles), 1̧ิ, Howard County, August 2006, (J. Jurzenski), 1 nymph, August 15, 2007,

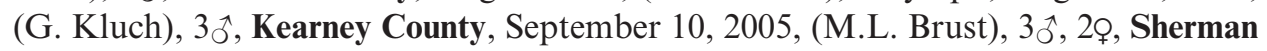
County, August 15, 2006, (S. Whipple), 10.

NEW STATE RECORD,

Nebraska specimens in USDA collection: 87

\section{Melanoplus bivittatus (Say)}

This grasshopper is found throughout Nebraska. While not common in rangeland in the western half of the state, it may be common along weedy roadsides and weedy patches in rangeland. It is frequently seen in gardens and can cause damage to crops. It is most common from early July to late August.

PREVIOUS RECORDS: Hauke 1953, Hagen 1970, Hagen and Rabe 1991.

SPECIMENS EXAMINED: Blaine County, July 19, 2005, (R.L. Soles), 20̂, Brown County, July 20, 2005, (R.L. Soles), 1@, Franklin County, July 21, 2005, (M.L.

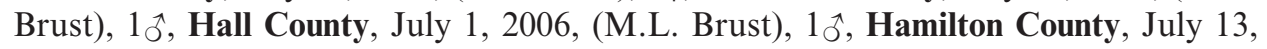

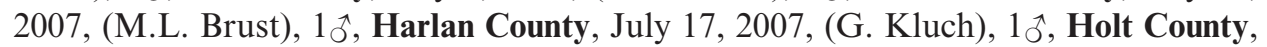

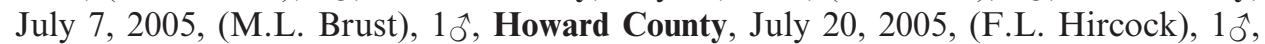
Johnson County, July 4, 2007, (M.L. Brust), 1今̄, Keya Paha County, August 16, 2005, (R.L. Soles), 1o, Pawnee County, July 2, 2005, (M.L. Brust), 1@, Rock County, July 7 ,

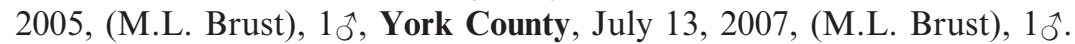

Nebraska specimens in USDA collection: 117

\section{*Melanoplus borealis (Fieber)}

Bruner (1893) stated that this species was common on low meadows during June and July. In other parts of its range it prefers low, moist areas. It was likely once widespread in eastern Nebraska before wetlands were largely drained for agriculture. It had not been collected in Nebraska for over a century until a strong population was located along Whitehorse Creek in Lincoln County in 2007. It likely occurs in other low, marshy areas, especially along cool, spring-fed streams. In Nebraska it has been collected commonly in July, but appears to become rare by August.

PREVIOUS RECORDS: Bruner 1893, Bruner 1897, Hauke 1953.

SPECIMENS EXAMINED: Lincoln County, July 11, 2007, (M.L. Brust), 1ð^, July 12, 2007 (M. L. Brust), 50ิ, 2ǫ.

NEW STATE RECORD.

Nebraska specimens in USDA collection: 30 


\section{Melanoplus bowditchi Scudder}

This colorful grasshopper occurs among sagebrush (Artemeisia sp.) and is seldom seen far from its preferred hosts. It appears limited mostly to the western third of Nebraska. It is very similar to M. flavidus and is easily confused with it. It is most easily differentiated by the colors of the outer hind femur and the shape of the tips of the furculae of the male. Peak numbers occur from mid-July to late August.

PREVIOUS RECORDS: Hauke 1953, Hagen 1970.

SPECIMENS EXAMINED: Chase County, August 16, 2005, (G.L. Thorson), 10, Hitchcock County, July 18, 2005, (G.L. Thorson), 19, Keith County, July 25, 2006,

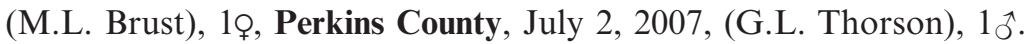

Nebraska specimens in USDA collection: 113

\section{Melanoplus bruneri Scudder}

The only known specimens of this species from Nebraska are in the U.S National Museum Collection. Specimens from the original type series from Scudder (1897) were collected from Gordon, Sheridan County. It reportedly prefers brushy and wooded habitats.

PREVIOUS RECORDS: Scudder 1897, Hauke 1953.

Nebraska specimens in USDA collection: 0

\section{Melanoplus confusus Scudder}

This is a common species in grasslands throughout Nebraska. It is the earliest Melanoplus species in the state, and peak numbers occur from late May to mid-July.

PREVIOUS RECORDS: Hauke 1953, Hagen 1970, Hagen and Rabe 1991.

SPECIMENS EXAMINED: Arthur County, June 8, 2005, (S.M. Jensen), 1ðぇ, Dawson County, June 21, 2005, (M.L. Brust), 10َ, 3o, Dundy County, July 15, 2005, (G.L. Thorson), 1ð^, Grant County, August 3, 2005, (M.L. Brust), 1o, Hall County,

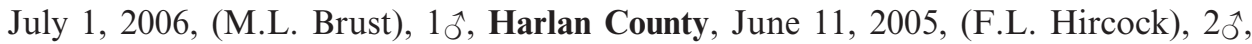
Hooker County, June 7, 2005, (M.L. Brust), 1今ે, Jefferson County, June 25, 2005,

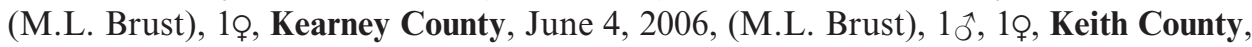
June 20, 2006, (M.L. Brust), 1o, Knox County, July 6, 2005, (M.L. Brust), 10ิ, Logan County, June 8, 2005, (S.M. Jensen), 1今ึ, Pawnee County, July 2, 2005, (M.L. Brust), 1Q, Phelps County, June 8, 2005, (F.L. Hircock), 1ㅅ, 1o, Richardson County, July 2, 2005, (M.L. Brust), 1@, Saline County, June 30, 2007, (M.L. Brust), 10َ, Stanton County, June 3, 2005, (M.L. Brust), 1ठㅊ, Thomas County, June 6, 2005, (M.L. Brust), $3 \hat{0}, 2$.

Nebraska specimens in USDA collection: 335

\section{Melanoplus dawsoni (Scudder)}

This small melanopline has been collected from a number of locations across Nebraska. It is most common in shrubby areas or among open woodlands. Hagen (1970) reports this species only from areas of pine and cedar forests. Peak numbers occur from early July to late August.

PREVIOUS RECORDS: Hauke 1953, Hagen 1970, Hagen and Rabe 1991.

SPECIMENS EXAMINED: Arthur County, August 9, 2007, (S.M. Jensen), 1ðَ, Blaine County, July 20, 2006, (R.L. Soles), 2ð⿱ , 1o, Grant County, July 20, 2005,

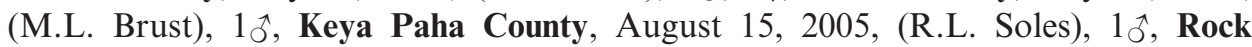


County, June 26, 2005, (R.L. Soles), 1o, Thomas County, August 29, 2005, (S.M. Jensen), 1§, 3o.

Nebraska specimens in USDA collection: 48

\section{Melanoplus differentialis (Thomas)}

This is a familiar and destructive species. It has been known to do serious damage to crops, especially corn, as well as to local gardens. It is uncommon in rangelands in the western portions of the state, but can be common among roadside weeds in these areas. Peak numbers occur from mid-July to early September.

PREVIOUS RECORDS: Hauke 1953, Hagen 1970, Hagen and Rabe 1991.

SPECIMENS EXAMINED: Franklin County, July 21, 2005, (M.L. Brust), 1 $\widehat{o}$, Greeley County, July 30, 3007, (A. Bauer; 4-H), 1今̄, Holt County, August 7, 2007, (R.L. Soles), 1o, Howard County, August 20, 2006, (M.L. Brust), 1ð, Pawnee County, July 23, 2005, (M.L. Brust), 1Q, Phelps County, July 27, 2005, (F.L. Hircock), 1o, Rock County, July 25, 2005, (R.L. Soles), 1ðึ.

Nebraska specimens in USDA collection: 100

\section{Melanoplus discolor (Scudder)}

This grasshopper is similar in appearance to $M$. dawsoni but slightly larger, and it generally lacks dark bars on the outer hind femur. While it is common in states to the south, it is rare and highly localized in Nebraska. All recent collections from Nebraska have been from low flats in the sandhills where this species appears to feed on falseboneset (Brickellia eupatorioides (L.)). It may be fairly common where found, but populations appear to be widely dispersed and limited in size. Most Nebraska collections have been from the second half of July and August

PREVIOUS RECORDS: Mulkern et al. 1969, Hagen and Rabe 1991.

SPECIMENS EXAMINED: Arthur County, August 2, 2006, (S.M. Jensen), 1o, Cherry County, August 9, 2005, (R.L. Soles), 1َ̧, 1\%, Hooker County, August 14, 2006, (S.M. Jensen), 1ðै, McPherson County, August 9, 2006, (S.M. Jensen), 2Q,

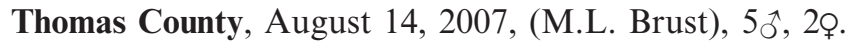

Nebraska specimens in USDA collection: 48

\section{Melanoplus fasciatus (Walker)}

This is strictly a woodland species. All collections in Nebraska have been from areas near the Missouri River. It is seldom common but can be found in small areas in hilltop areas in woodlands. Indian Cave State Park supports a stable population. Peak numbers occur from late July to early September.

PREVIOUS RECORDS: Hauke 1953.

SPECIMENS EXAMINED: Richardson County, August 12, 2006, (M. L. Brust), 2 o.

Nebraska specimens in USDA collection: 4

\section{Melanoplus femurrubrum (DeGeer)}

This grasshopper is common throughout Nebraska. It can be common in weedy rangeland but is best known as a crop pest. Peak numbers occur from late July to mid-September.

PREVIOUS RECORDS: Hauke 1953, Mulkern et al. 1969, Hagen 1970, Hagen and Rabe 1991. 
SPECIMENS EXAMINED: Boyd County, July 7, 2005, (M.L. Brust), 2へ̂, Greeley County, August 15, 2005, (F.L. Hircock), 10̂, Holt County, August 3, 2005, (R.L. Soles), 1ðิ, 1o, Howard County, August 20, 2006, (M.L. Brust), 1o, Rock County, July 25, 2005, (R.L. Soles), 1今ึ.

Nebraska specimens in USDA collection: 384

\section{Melanoplus flavidus Scudder}

This grasshopper can be common in sandy areas, particularly with an abundance of sunflower. In Nebraska, it is most numerous in the sandhills. It is confusingly similar to $M$. bowditchi in appearance. Peak numbers occur from mid-July to early September.

PREVIOUS RECORDS: Hauke 1953, Hagen 1970, Hagen and Rabe 1991.

SPECIMENS EXAMINED: Arthur County, July 14, 2005, (S.M. Jensen), 1へ̋, 1Q, Blaine County, July 28, 2005, (M.L. Brust), 2̧ૈ, Box Butte County, July 28, 2006, (D.A. Widhalm), 1\%, Brown County, August 1, 2005, (M.L. Brust), 1ðै, Custer County, July 27, 2006, (M.L. Brust), 1o, Garden County, August 16, 2005, (S.M.

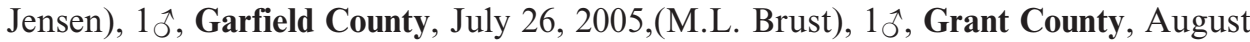

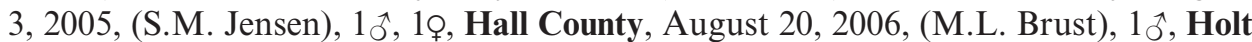
County, August 15, 2005, (R.L. Soles), 1o, Hooker County, August 10, 2005, (S.M.

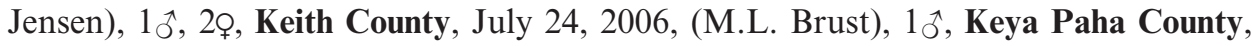
August 2, 2007, (R.L. Soles), 2^, 2o, Logan County, August 8, 2005, (S.M. Jensen),

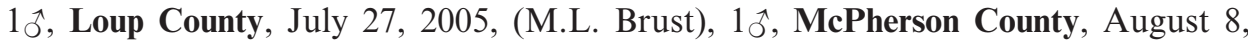
2005, (S.M. Jensen), 1ð, Morrill County, September 1, 2005, (S.M. Jensen), 1o, Rock County, July 25, 2005, (R.L. Soles), 1今̄, Scotts Bluff County, July 18, 2007, (D.A. Widhalm), 1今̄, Sheridan County, August 30, 2005, (S.M. Jensen), 1o, Wheeler County, July 26, 2005, (M.L. Brust), 2ર̂, 1 .

Nebraska specimens in USDA collection: 191

\section{Melanoplus fluviatilis Bruner}

This grasshopper has been recognized only as a subspecies of Melanoplus foedus in recent years, but recent work by the first author suggests it is likely a good species. It is treated here as a separate species. It differs from $M$. foedus in appearance and habitat. It is not normally found alongside $M$. foedus, intergrades have not been found, and its distribution broadly overlaps with that of $M$. foedus. It has been found, often abundantly, in open woodlands along rivers, especially the Platte and Republican Rivers. Some specimens previously listed as M. foedus in the State Museum collection from the eastern part of the state appear to be this species. Peak numbers occur from early July to early September.

PREVIOUS RECORDS: Bruner 1897 (no county records).

SPECIMENS EXAMINED: Buffalo County, September 10, 2005, (M.L. Brust), 1o, Cass County, August 24, 1913, (E.G. Anderson), 1@, Cuming County, September, no year, (L. Bruner) 1§ै, Dakota County, July 12, 1912, (L. Bruner), 2o, (previously listed as M. angustipennis), Dawson County, August 18, 2006, (M.L. Brust), 3ㅅ, 1o, Furnas County, September 3, 2007, (M.L. Brust), 4ㅇ, Kearney County, August 18, 2005, (M.L. Brust), 1今, Keith County, July 25, 2006, (M.L. Brust), 30ิ, 5o, Knox County, (M.H. Swenk), no date, 1o, Lincoln County, June 20, 2006, (M.L. Brust), 1 Q .

Nebraska specimens in USDA collection: 151 


\section{Melanoplus foedus (Scudder)}

This grasshopper has often been confused with M. packardii. Hagen (1970) stated that most specimens from the panhandle had blue tibiae. This contrasts with recent collections from throughout the western two-thirds of the state from which greater than $90 \%$ had pinkish red tibiae. Habitat can be useful to differentiate these two species, because $M$. foedus prefers sandy areas while $M$. packardii prefers heavier soils. Apparent hybrids between these two species have been found at a few scattered locations, but these two species only co-occur rarely. Because of the discrepancies in the stated appearance of these species in Hagen (1970), many of the records from the panhandle are questionable. The State Museum contains large series of these two species, and a great deal of time could be spent re-examining the material. All records east of Holt County may be $M$. fluviatilis, but for now these records are included under both species as it was unknown if additional specimens from these counties existed. It is common throughout the sandhills as well as in other sandy areas throughout the western two-thirds of the state. Peak numbers occur from mid-July to late August.

PREVIOUS RECORDS: Hauke 1953, Hagen 1970.

SPECIMENS EXAMINED: Arthur County, July 13, 2005, (S.M. Jensen), 1乞ิ, Blaine County, July 26, 2005, (M.L. Brust), 1へै, 1o, Box Butte County, July 24, 2006, (D.A. Widhalm), 2َ̧, Brown County, July 25, 2006, (R.L. Soles), 1Q, Cherry County, July 20, 2005, (S.M. Jensen), 1ิึ, Custer County, August 27, 2005, (M.L. Brust), 1o, Grant County,

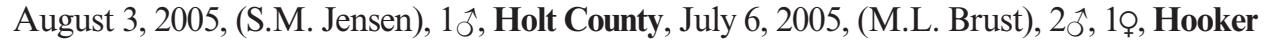
County, July 30, 2007, (S.M. Jensen), 1@, Keith County, August 11, 2005, (G.L. Thorson), 1乞ิ, Lincoln County, July 11, 2007, (M.L. Brust), 1ô, 1ơ, Logan County, August 8, 2005, (S.M. Jensen), 1ф, Red Willow County, July 26, 2005, (G.L. Thorson), 1@, Rock County,

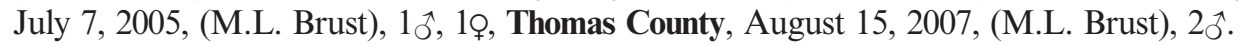

Nebraska specimens in USDA collection: 279

\section{Melanoplus gladstoni Scudder}

This grasshopper has been found throughout the panhandle, from Dundy County, and from along the northern edge of the state. Hagen (1970) reports it as common throughout the panhandle. It prefers gravelly soils, and perhaps its scarcity across most of the state can be attributed to a general lack of dry, gravelly habitats. Most Nebraska records are from July and August.

PREVIOUS RECORDS: Hauke 1953, Hagen 1970, Hagen and Rabe 1991.

SPECIMENS EXAMINED: Brown County, August 12, 2007, (S. Whipple), 20ิ, Keya Paha County, August 16, 2005, (R.L. Soles), 10^.

Nebraska specimens in USDA collection: 16

\section{Melanoplus gracilis (Bruner)}

Only one specimen of this woodland species is found in the State Museum. Bruner (1897) stated that it was found quite abundantly in woodlands in the eastern part of the state. Its current status in Nebraska remains unknown.

PREVIOUS RECORDS: Hauke 1953.

Nebraska specimens in USDA collection: 0

\section{Melanoplus huroni Blatchley}

Only one Nebraska specimen is known from Sioux County. As this is typically a mountain forest species, the collection most likely occurred in the Pine Ridge. 
PREVIOUS RECORDS: Hauke 1953.

Nebraska specimens in USDA collection: 0

\section{Melanoplus infantilis (Scudder)}

This is a common species throughout the panhandle and has been collected at a few locations further east. It typically inhabits shortgrass rangeland. Peak numbers occur from mid-July to early September.

PREVIOUS RECORDS: Hauke 1953, Hagen 1970, Hagen and Rabe 1991.

Nebraska specimens in USDA collection: 72

\section{Melanoplus keeleri (Thomas)}

This grasshopper has been recorded throughout Nebraska from scattered locations. It is most common in grasslands with numerous bare patches, but appears to be lacking from much of the sandhills. It may be overlooked in many areas as it is a late season species. Peak numbers occur from early August to midSeptember.

PREVIOUS RECORDS: Hauke 1953, Hagen 1970, Hagen and Rabe 1991.

SPECIMENS EXAMINED: Boyd County, August 21, 2006, (R.L. Soles), 20ै, Brown County, July 20, 2005, (R.L. Soles), 1 nymph, Buffalo County, July 28, 2006,

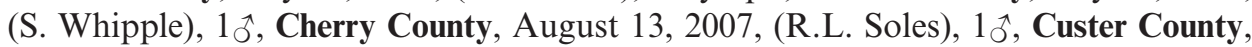
July 26, 2006, (S. Whipple), 1o, Gage County, October 7, 2006, (M.L. Brust), 10ิ, 1o, Hall County, July 1, 2006, (M.L. Brust), 1 nymph, Holt County, August 16, 2005,

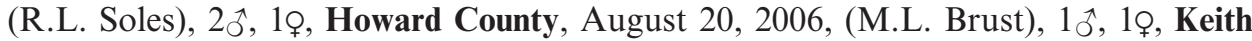
County, August 14, 2007, (G.L. Thorson), 1^^, Keya Paha County, August 15, 2005, (R.L. Soles), 1ठ, 2Q, Pawnee County, September 3, 2005, (M.L. Brust), 1o, Red Willow County, August 21, 2007, (G.L. Thorson), 19, Rock County, July 26, 2005, (R.L. Soles), 1 nymph, Thomas County, August 11, 2005, (S.M. Jensen), 1Q, Valley County, August 16, 2005, (F.L. Hircock), 1今̄, Wheeler County, August 2, 2005, (R.L. Soles), 1 今.

Nebraska specimens in USDA collection: 96

\section{Melanoplus lakinus (Scudder)}

This species occurs across most of the western two-thirds of Nebraska in local populations. It feeds primarily on members of the Chenopodiaceae, and it can be locally common among these plants. It is typically brachypterous, but long-winged females are not rare. Peak numbers occur from mid-July to late August.

PREVIOUS RECORDS: Hauke 1953, Hagen 1970, Hagen and Rabe 1991.

SPECIMENS EXAMINED: Arthur County, August 1, 2006, (S.M. Jensen), 1ð^, 3o, Buffalo County, August 12, 2006, (S. Whipple), 1\%, Chase County, August 17, 2005, (G.L. Thorson), 2o, Dawson County, July 23, 2007, (M.L. Brust), 1o, Frontier County,

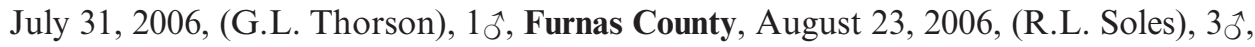
Harlan County, August 22, 2006, (R.L. Soles), 1o, Hayes County, July 25, 2006, (G.L.

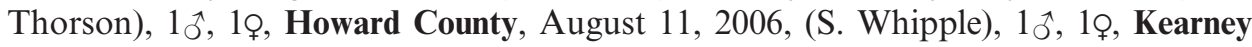
County, July 26, 2007, (M.L. Brust), 1क् , Keith County, July 25, 2006, (M.L. Brust), 4ô, 3o, Knox County, July 31, 2007, (R.L. Soles), 1ðૈ, 1o, Lincoln County, August 8, 2005, (G.L. Thorson), 1§ै, 2o, Logan County, June 14, 2007, (D. Schaeffer; 4-H), 1o, Phelps County, July 27, 2006, (S. Whipple), 1ð̋, Sherman County, August 15, 2005, (F.L. Hircock), 1Q, Thomas County, August 16, 2007, (M.L. Brust), 1今^, 1 . . 
Nebraska specimens in USDA collection: 142

Melanoplus occidentalis (Thomas)

This species inhabits shortgrass rangeland in western Nebraska and is seldom numerous. Peak numbers occur from late June to mid-September.

PREVIOUS RECORDS: Hauke 1953, Mulkern et al. 1969, Hagen 1970.

SPECIMENS EXAMINED: Chase County, August 16, 2005, (G.L. Thorson), 1o, Hayes County, July 19, 2005, (G.L. Thorson), 2ર̂, Keith County, June 26, 2006, (G.L. Thorson), 1o.

Nebraska specimens in USDA collection: 26

\section{Melanoplus packardii Scudder}

This species is similar to M. foedus. Several previous records for this species are most likely $M$. foedus because $M$. packardii is not expected to occur in the sandhills. This species is most common on heavy soils such as clay or loess and inhabits grasslands and weedy roadsides with abundant bare soil areas. Peak numbers occur from early July to late August.

PREVIOUS RECORDS: Hauke 1953, Hagen 1970, Hagen and Rabe 1991.

SPECIMENS EXAMINED: Buffalo County, July 13, 2007, (G. Kluch), 1o, Franklin County, July 21, 2005, (M.L. Brust), 4ô,, 1Q, Furnas County, July 16, 2007, (G. Kluch), 1o, Gage County, October 7, 2006, (M.L. Brust), 1@, Gosper County,

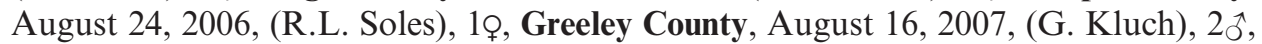
Harlan County, August 23, 2006, (R.L. Soles), 1Q, Howard County, August 20, 2006, (M.L. Brust), 1o, Keith County, July 25, 2006, (M.L. Brust), 1ㅅ, 2o, Knox County,

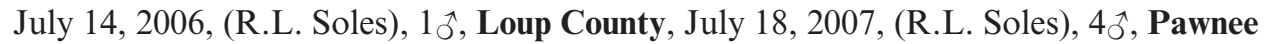
County, July 22, 2006, (M.L. Brust), 4^઼, 1ㅇ, Sherman County, July 25, 2005, (F.L. Hircock), 1 . .

Nebraska specimens in USDA collection: 132

*Melanoplus punctulatus Scudder

Bruner (1897) stated that this species was found in rather small numbers in oak groves in the extreme eastern part of the state. It was rediscovered in 2007 when a single female was collected at Indian Cave State Park. It is reportedly an arboreal species.

PREVIOUS RECORDS: Bruner 1897, Hauke 1953.

SPECIMENS EXAMINED: Richardson County, July 14, 2007, (M.L. Brust), 1 ọ. NEW STATE RECORD.

Nebraska specimens in USDA collection: 1

\section{Melanoplus sanguinipes (Fabricius)}

This is a common species throughout Nebraska, occurring in a wide variety of habitats. It is known to be destructive to both rangeland and crops. Peak numbers occur from early July to late August.

PREVIOUS RECORDS: Hauke 1953, Hagen 1970, Hagen and Rabe 1991.

SPECIMENS EXAMINED: Frontier County, July 27, 2005, (G.L. Thorson), 1ð^, Harlan County, August 22, 2006, (R.L. Soles), 1o, Hooker County, August 11, 2005, (S.M. Jensen), 1o, Keya Paha County, August 7, 2006, (R.L. Soles), 1o, Rock County, July 26, 2005, (R.L. Soles), 1へ̂. 
Nebraska specimens in USDA collection: 316

\section{Melanoplus scudderi (Uhler)}

This small, brachypterous species has only been collected from the eastern third of Nebraska. It has been found commonly along eroded gravelly hillsides at a site in Gage County, but has been found sparingly elsewhere. It is a late-season species, with peak numbers from mid-August to early October.

PREVIOUS RECORDS: Hauke 1953.

SPECIMENS EXAMINED: Gage County, July 22, 2006, (M.L. Brust), 1ð^, Richardson County, August 12, 2006, (M.L. Brust), 1 ô.

Nebraska specimens in USDA collection: 48

\section{Melanoplus walshii Scudder}

This woodland species has only been collected from a few areas near the Missouri River in Nebraska. It is not common, and while it has been collected in the same general areas as $M$. fasciatus, the two species have not been found together at the same sites. It appears to prefer lower slopes in woodlands. It is distinctly larger than M. fasciatus, and the pale areas on the dorsal tegmina are distinctive. Nebraska collections are from August and September.

PREVIOUS RECORDS: Hauke 1953.

SPECIMENS EXAMINED: Richardson County, August 12, 2006, (M.L. Brust), $2 \hat{0}$.

Nebraska specimens in USDA collection: 6

\section{*Paratylotropidia brunneri Scudder}

This woodland species is rare throughout its range. The Nebraska collections occurred in tallgrass prairie near a row of trees, as well as among young elms along the edge of an oak woodland.

SPECIMENS EXAMINED: Pawnee County, June 25, 2005, (M.L. Brust), 1へર, Richardson County, July 4, 2006, (M.L. Brust), $1 \hat{\jmath}$, 1 ㅇ.

NEW STATE RECORD.

Nebraska specimens in USDA collection: 3

\section{Phoetaliotes nebrascensis (Thomas)}

This is a common species throughout Nebraska. Adults are most often brachypterous, but long-winged forms of both sexes are not uncommon. Peak numbers occur from late July to late September.

PREVIOUS RECORDS: Hauke 1953, Hagen 1970, Hagen and Rabe 1991.

SPECIMENS EXAMINED: Boyd County, August 18, 2005, (R.L. Soles), 1ㅊ, Hall County, August 20, 2006, (M.L. Brust), 1ð, Hamilton County, July 13, 2007,

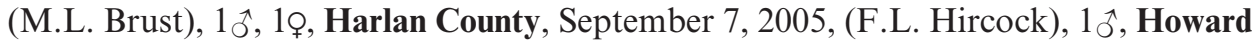
County, August 20, 2006, (M.L. Brust), 1§̄, Keya Paha County, August 16, 2005,

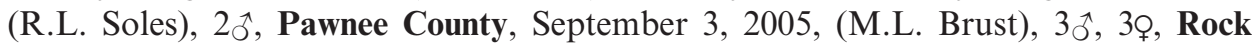

County, July 26, 2005, (R.L. Soles), $1 \widehat{\jmath}$.

Nebraska specimens in USDA collection: 196

\section{Oedipodinae}

Arphia conspersa Scudder 
The hind wing cell is typically pinkish red across most of the state, but orange or yellow-winged forms become common in the region of the Pine Ridge. It is expected to occur virtually throughout Nebraska. This is an early season bandwing with peak numbers occurring from mid-April to early June.

PREVIOUS RECORDS: Hauke 1953, Mulkern et al. 1969, Hagen 1970, Hagen and Rabe 1991.

SPECIMENS EXAMINED: Butler County, May 13, 2007 (M.L. Brust), 1ơ, Chase County, May 18, 2005, (M.L. Brust), 1ð̊, Furnas County, May 19, 2005, (M.L. Brust), 1ð̋, Gage County, May 4, 2007, (M.L. Brust), 1@, Greeley County, April 14, 2006, (M.L. Brust), 3ô, Hall County, April 23, 2005, (M.L. Brust),1o, Harlan County, April 22, 2006, (M.L. Brust), 2ᄋ, Hayes County, May 18, 2005, (M.L. Brust), 1\%, Hitchcock County, May 18, 2005, (M.L. Brust), 1o, Jefferson County, June 25, 2005, (M.L. Brust), 1@, Keith County, May 25, 2006, (M.L. Brust),1 ô, Perkins County, May 18, 2005, (M.L. Brust), 1̧ิ, 2o, Platte County, April 4, 2006, (M.L.

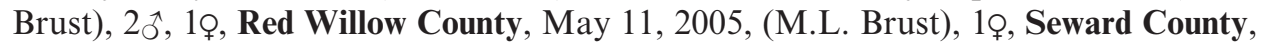
April 9, 2006, (M.L. Brust), 4ð, Sherman County, April 15, 2006, (M.L. Brust), 2ో, 1ㅇ, Wheeler County, May 10, 2006, (R.L. Soles), 1ð.

Nebraska specimens in USDA collection: 169

\section{Arphia pseudonietana (Thomas)}

The crimson and black hind wings with a long black spur are distinctive. It occurs in a variety of rangeland habitats but appears most consistent in the northern half of the state. Peak numbers occur from late July to mid-September.

PREVIOUS RECORDS: Hauke 1953, Hagen 1970, Hagen and Rabe 1991.

SPECIMENS EXAMINED: Dawson County, July 26, 2006, (S. Whipple), 1 . .

Nebraska specimens in USDA collection: 71

\section{Arphia simplex Scudder}

This grasshopper is distinctive in having yellow hind wings and a narrow black band with a long spur. It occurs in tallgrass habitats and low areas in mixed-grass. It appears to be limited primarily to the eastern half of Nebraska, with Hitchcock County currently marking its westernmost occurrence. One individual was seen in Keith County in 2007, but evaded capture. Peak numbers of this species occur from mid-May to early July.

PREVIOUS RECORDS: Hauke 1953.

SPECIMENS EXAMINED: Custer County, June 14, 2005, (M.L. Brust), 3ð̋, 2o, Dawson County, June 21, 2005, (M.L. Brust), 1今ึ, Franklin County, July 21, 2005,

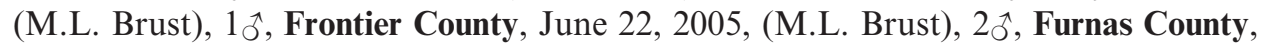
June 22, 2005, (M.L. Brust), 1ơ, 1ǫ, Gage County, June 24, 2007 (M.L. Brust), $1 \widehat{\jmath}$,Gosper County, June 21, 2005, (M.L. Brust), 1ðै, Hall County, June 20, 2005,

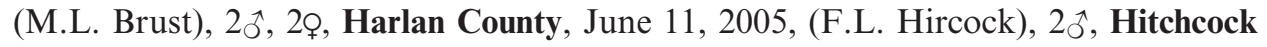
County, July 25, 2006, (G.L. Thorson), 1今̄, Johnson County, July 4, 2007, (M.L.

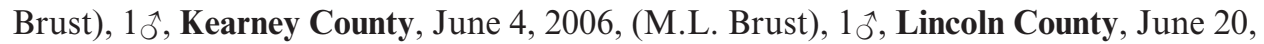
2006, (M.L. Brust), 1ð̊, Pawnee County, July 2, 2005, (M.L. Brust), 1o, Red Willow County, May 19, 2005, (M.L. Brust), 5ð̊, 1@, Richardson County, July 2, 2005, (M.L. Brust), 2^, Saline County, June 30, 2007, (M.L. Brust), 1o, Seward County, May 22, 2005, (M.L. Brust), 1Q, Thomas County, July 18, 2004, (C. Aubushon; 4-H), $1 \overbrace{}^{\hat{0}}$.

Nebraska specimens in USDA collection: 105 


\section{Arphia xanthoptera (Burmeister)}

This bandwing can be distinguished from other Arphia species by its strongly arched pronotum. The hind wings have a broad black band, but with a poorly developed spur. The disk color ranges from red to yellow. Peak numbers of this grasshopper occur from late July to late September.

PREVIOUS RECORDS: Hauke 1953, Hagen and Rabe 1991.

SPECIMENS EXAMINED: Blaine County, July 28, 2005, (M.L. Brust), 4ðิ, 1\%, Brown County, July 20, 2005, (R.L. Soles), 1 nymph, Buffalo County, August 20,

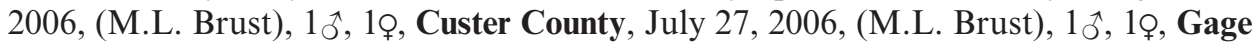
County, July 22, 2006, (M.L. Brust), 1Q, Garden County, August 16, 2005, (S.M. Jensen), 1Q, Garfield County, July 27, 2005, (M.L. Brust), 1ㅅ, 1Q, Grant County, August 14, 2007, (M.L. Brust), 1§ิ, Holt County, August 4, 2005, (R.L. Soles), 1o, Hooker County, August 14, 2007, (M.L. Brust), 1ðَ, Howard County, July 29, 2005,

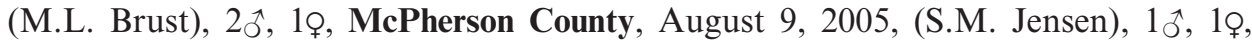
Nemaha County, August 12, 2006, (M.L. Brust), 1o, Otoe County, August 25, 2007, (M.L. Brust), 1o, Pawnee County, September 3, 2005, (M.L. Brust), 1o, Richardson County, August 12, 2006, (M.L. Brust), 1o, Rock County, July 27, 2006, (R.L. Soles),

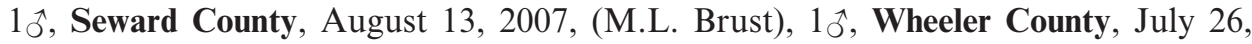
2005, (M.L. Brust), 1今.

Nebraska specimens in USDA collection: 100

\section{Camnula pellucida (Scudder)}

This is mostly a northern species that appears limited to northern Nebraska. It has also recently been detected in two counties in the central sandhills. Perhaps microhabitat conditions have allowed it to survive in isolated locations in these two counties. Peak numbers occur from late June to mid-August.

PREVIOUS RECORDS: Hauke 1953, Hagen and Rabe 1991.

SPECIMENS EXAMINED: Grant County, July 14, 2007, (M. Giovanni, L. Thacker-Lynne, L. Anderson), 1o, Hooker County, June 28, 2007, (M. Giovanni, L. Thacker-Lynne, L. Anderson), 3今̄, 3 nymphs.

Nebraska specimens in USDA collection: 14

\section{Chortophaga viridifasciata (DeGeer)}

This is a common springtime bandwing throughout Nebraska. In the eastern part of the state it occurs in a variety of grassy habitats but becomes restricted to low, moist areas to the west. Its seasonal occurrence is unusual. Adults are common from the end of March to mid-June, and a few spring adults linger into July. In midAugust nymphs from the spring individuals have reached second and third instar, and adults appear a second time, but at low densities. A few adults from this group may linger until mid-October. These late season adults differ from the spring adults in being more heavily patterned and most often having blue tibiae (usually tan or pink in spring). Many of these late season adults key out to C. austalior in Otte (1984). The general lack of overlap in adult occurrence suggests that gene flow may be limited between these broods. The geographic morphology variation and seasonality of this species requires further study and it may consist of more than one species, or that all forms within the genus represent a single, highly variable species. The summer form has been caught at lights.

PREVIOUS RECORDS: Hauke 1953, Hagen 1970, Hagen and Rabe 1991. 
SPECIMENS EXAMINED: Butler County, May 13, 2007 (M.L. Brust), 10ิ, Buffalo County, May 19, 2005, (M.L. Brust), 1o, Chase County, May 18, 2005, (M.L.

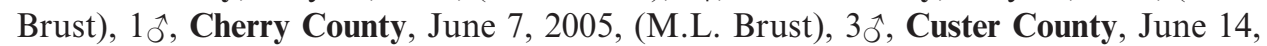
2005, (M.L. Brust), 1§઼, Dawson County, May 19, 2005, (M.L. Brust), 1ð^, Dodge County, June 3, 2005, (M.L. Brust), 1ðَ, Gage County, May 4, 2007, (M.L. Brust), 1§ิ, Garfield County, May 8, 2006, (R.L. Soles), 2ð, Hall County, June 20, 2005,

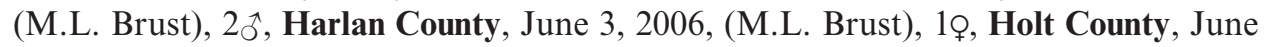
21, 2006, (R.L. Soles), 1ô, Jefferson County, June 25, 2005, (M.L. Brust), 1o,, Johnson County, July 4, 2007 (M.L. Brust), 1今̄, Keya Paha County, May 23, 2006, (M.L. Brust), 1ð̊, Lincoln County, May 9, 2005, (M.L. Brust), 1@, Loup County, May

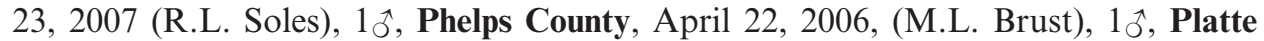
County, April 28, 2007, (M.L. Brust), 1今̄, Red Willow County, June 7, 2005, (G.L. Thorson), 1ðَ, Rock County, May 23, 2006, (M.L. Brust), 1o, Saunders County, April 14, 2006, (M .L. Brust), 1क, Seward County, May 22, 2005, (M.L. Brust), 2َ̧, 2o, Sherman County, April 15, 2006, (M.L. Brust), 20.

Nebraska specimens in USDA collection: 218

\section{Circotettix rabula Rehn and Hebard}

This grasshopper has been recorded from throughout the Nebraska panhandle. It prefers eroded hillsides and similar barren areas. In flight, it is our loudest crepitator. Peak numbers occur in July and August.

PREVIOUS RECORDS: Hauke 1953, Hagen 1970.

Nebraska specimens in USDA collection: 11

\section{Cratypedes neglectus (Thomas)}

Only a single male specimen exists in the State Museum from Cheyenne County. Bruner (1897) mentions it from Sioux County, but it has not been collected there in the past century. This bandwing apparently occurs in July and August.

PREVIOUS RECORDS: Hauke 1953.

Nebraska specimens in USDA collection: 0

\section{Derotmema haydeni (Say)}

This small bandwing is limited to the western half of Nebraska. It turns up at low densities in shortgrass rangeland. In 2006, a population was found on river gravel along the Platte River at Ogallala. A subsequent visit in 2007 failed to locate any additional specimens and it is suspected the population may have been decimated by floods in June of that year. The hind wing disc may be pinkish red or yellow. Peak numbers occur from mid-July to late August.

PREVIOUS RECORDS: Hauke 1953, Hagen 1970.

SPECIMENS EXAMINED: Hayes County, July 25, 2006, (G.L. Thorson), 1@, Keith County, June 22, 2006, (M.L. Brust), $10 \widehat{~}$.

Nebraska specimens in USDA collection: 39

\section{Dissosteira carolina (Linnaeus)}

This is the familiar "parking lot grasshopper". It is common in many humanaltered environments and appears to especially prefer areas with abundant gravel. It is uncommon in rangeland. Peak numbers occur from early July to late August.

PREVIOUS RECORDS: Hauke 1953, Hagen 1970, Hagen and Rabe 1991. 
SPECIMENS EXAMINED: Franklin County, July 21, 2005, (M.L. Brust), 2ð, Gage County, June 26, 2005, (M.L. Brust), 1o, Howard County, August 20, 2006, (M.L. Brust), 10ิ, Keya Paha County, August 2, 2007, (R.L. Soles), 1ǫ, Richardson

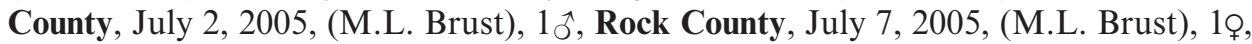
Seward County, August 13, 2007, (M.L. Brust), 1o, York County, August 13, 2007, (M.L. Brust), 10ิ.

Nebraska specimens in USDA collection: 57

\section{Dissosteira longipennis (Thomas)}

This grasshopper was known to occur in Nebraska regularly in the 1930's, especially during outbreaks in its primary breeding areas in Colorado and New Mexico. It remained unrecorded (from sweep samples) in the state since that time until specimens were secured from three counties in 2006 and 2007. Peak numbers occur from early July to late August.

PREVIOUS RECORDS: Hauke 1953.

SPECIMENS EXAMINED: Buffalo County, August 2, 2006, (S. Whipple), 1o, Morrill County, July 24, 2007, (M.L. Brust), 1へ̂, Scotts Bluff County, July 25, 2007, (M.L. Brust), 1 Q .

Nebraska specimens in USDA collection: 3

\section{Encoptolophus costalis (Scudder)}

This grasshopper has an unusual distribution in Nebraska. It has been collected from all panhandle counties and is common in many counties in central Nebraska. Most records from the eastern two-thirds of the state have occurred in the past three years. The Douglas County record is questionable and may represent E. sordidus. Peak numbers occur from late July to mid-September.

PREVIOUS RECORDS: Hauke 1953, Hagen 1970.

SPECIMENS EXAMINED: Antelope County, August 10, 2007, (S. Whipple), 1o, Boyd County, August 18, 2005, (R.L. Soles), 2^^, Brown County, August 12, 2007, (S. Whipple), 1o, Buffalo County, July 28, 2006, (S. Whipple), 1今, Cherry County, August 8, 2006, (R.L. Soles), 10ิ, Custer County, July 26, 2006, (S. Whipple), 10ิ, Frontier County, August 22, 2007, (G.L. Thorson), 1ㅅ, Furnas County, August 23, 2006, (R.L. Soles), 1@, Garfield County, August 24, 2005, (F.L. Hircock), 1o, Greeley County, August 16, 2007, (G. Kluch), 2̧, Harlan County, August 22, 2006, (R.L.

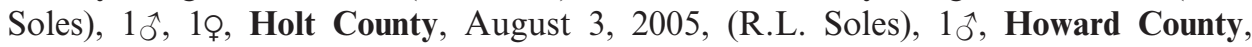

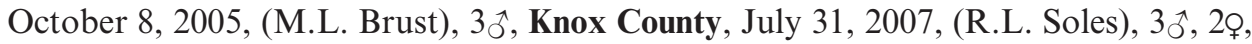
Sherman County, August 16, 2006, (S. Whipple), 2o, Valley County, August 16, 2005, (F.L. Hircock), 1Q.

Nebraska specimens in USDA collection: 57

\section{Encoptolophus sordidus (Burmeister)}

This grasshopper is locally common in grassland in the eastern part of Nebraska. Both recent records from the central part of the state occured in low areas near streams or ditches. The Sheridan County record is questionable and may represent E. costalis.

PREVIOUS RECORDS: Hauke 1953, Hagen and Rabe 1991.

SPECIMENS EXAMINED: Furnas County, September 3, 2007, (M.L. Brust), 10ै, Garfield County, August 28, 2005 (M.L. Brust), 1o, Kearney County, September 10, 


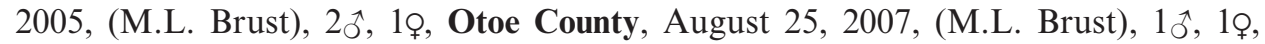
Rock County, August 1, 2007, (R.L. Soles), 1 $\widehat{0}$.

Nebraska specimens in USDA collection: 47

\section{*Encoptolophus subgracilis Caudell}

This primarily southwestern species has long escaped detection in Nebraska. It occurs locally in South Dakota in alkaline areas. Hauke (1953) speculated that it might occur in the eastern and southern parts of the state. It has recently been found to occur in three saline areas in the vicinity of Lincoln in Lancaster County. Populations appear to be highly localized. Peak numbers occur from late July to mid-September.

SPECIMENS EXAMINED: Lancaster County, September 20, 2006, (M.L. Brust), 3今̄, 3o, NEW STATE RECORD.

Nebraska specimens in USDA collection: 16

\section{Hadrotettix trifasciatus (Say)}

This bandwing occurs across all of Nebraska. In the shortgrass rangeland of the panhandle it can be found among bare soil patches, but it becomes restricted to eroded hillsides and human altered areas such as roadcuts in the eastern half of the state. It can be locally abundant. Peak numbers occur from early July to early September.

PREVIOUS RECORDS: Hauke 1953, Hagen 1970, Hagen and Rabe 1991.

SPECIMENS EXAMINED: Gage County, July 22, 2006, (M.L. Brust), 3ðै, 3o

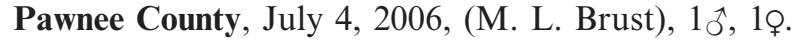

Nebraska specimens in USDA collection: 59

\section{Hippiscus ocelote (Saussure)}

This bandwing occurs throughout Nebraska in a variety of rangeland habitats. The hind wing disc may be red or yellow, or rarely, orange. It is similar to Pardalophora haldemani but can be easily differentiated by the banding on the inner hind femur. It can be attracted to lights as three females were collected at a gas station under the lights at Ogallala in 2006. Peak numbers occur from late July to mid-September.

PREVIOUS RECORDS: Hauke 1953, Mulkern et al. 1969, Hagen 1970, Hagen and Rabe 1991.

SPECIMENS EXAMINED: Hall County, August 13, 2007, (M.L. Brust), 1o, Howard County, July 29, 2005, (M.L. Brust), 20ิ, 1ㅇ, Kearney County, September 10,

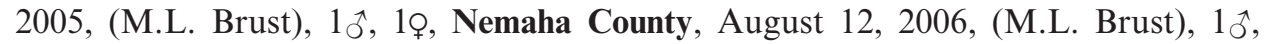
Pawnee County, September 3, 2005, (M.L. Brust), 20ิ, Richardson County, August 12, 2006, (M.L. Brust), 1@, Rock County, July 27, 2006, (R.L. Soles), 1ð^, Saline County, August 2, 2006, (B. Jackson; 4-H), 1 \%.

Nebraska specimens in USDA collection: 94

\section{Mestobregma plattei (Thomas)}

This bandwing has been collected throughout the panhandle counties. Hagen (1970) stated that it is generally a rare insect. In 2007 it was collected primarily from along the top edges of steep rocky slopes and was only moderately common in those areas. The hind wings are most often yellow, but may occasionally be red. Peak numbers occur from mid-July to early September. 
PREVIOUS RECORDS: Hauke 1953, Hagen 1970.

Nebraska specimens in USDA collection: 9

\section{Metator pardalinus (Saussure)}

This grasshopper has been collected mostly from the panhandle as well as from a few sites to the east. The hind wing disc is most often yellow or scarlet red but can vary from pink to orange as well. Hagen (1970) stated that only a few were found at any site. In 2007 it was found commonly at a single site in Morrill County, but absent from areas nearby. Most Nebraska collections have been from July to September.

PREVIOUS RECORDS: Hauke 1953, Hagen 1970.

Nebraska specimens in USDA collection: 19

\section{Pardalophora apiculata (Harris)}

This large bandwing occurs very early in the season. During warm springs, adults have been noted in central Nebraska as early as the third week of March. The color of the hind wing disc is pinkish. It has been collected from scattered locations throughout Nebraska. Peak numbers occur from early April to late May.

PREVIOUS RECORDS: See Hauke 1953, Hagen 1970.

SPECIMENS EXAMINED: Arthur County, May 18, 2005, (S.M. Jensen), 1o, Butler County, May 13, 2007 (M.L. Brust), 20ิ, Buffalo County, May 19, 2005, (M.L.

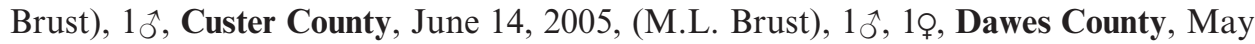
17, 2005, (D.A. Widhalm), 1@, Dawson County, April 22, 2006, (M.L. Brust), 3ðิ, Frontier County, May 19, 2005, (M.L. Brust), 1§̋, Gage County, May 4, 2007, (M.L. Brust), 1̧ิ, Garden County, June 16, 2005, (S.M. Jensen), 1@, Hall County, April 23, 2005, (M.L. Brust), 1o, Hayes County, May 18, 2005, (M.L. Brust), 1ð̊, Holt County, August 16, 2005, (R.L. Soles), 1 nymph, Hooker County, May 15, 2007 (M.L. Brust), 1̊, Jefferson County, May 14, 2005, (M.L. Brust), 1へર, Keith County, May 25, 2006, (M.L. Brust), 4ð̊, Keya Paha County, May 23, 2006, (M.L. Brust), 1ф, Knox County,

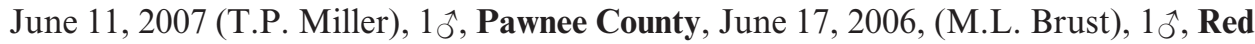
Willow County, May 19, 2005, (M.L. Brust), 3o, Rock County, May 23, 2006, (M.L.

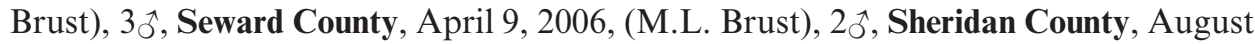
24, 2005, (R.L. Soles), 1 nymph, Sherman County, April 15, 2006, (M.L. Brust), 2 q.

Nebraska specimens in USDA collection: 83

\section{Pardalophora haldemani (Scudder)}

This large bandwing occurs throughout Nebraska. It has recently been found to be range-destructive as a large outbreak occurred in parts of Buffalo, Custer, and Dawson Counties in 2003 and 2004. The hind wings disc color may be yellow or pinkish red. Peak numbers occur from late May to mid-July.

PREVIOUS RECORDS: Hauke 1953, Hagen 1970, Hagen and Rabe 1991.

SPECIMENS EXAMINED: Gage County, June 24, 2007 (M.L. Brust), 1ð, Harlan County, June 11, 2005, (F.L. Hircock), 2ર̂, 19, Howard County, June 29, 2005, (M.L. Brust), 1ọ, Jefferson County, June 25, 2005, (M.L. Brust), 1ð̋, Kearney

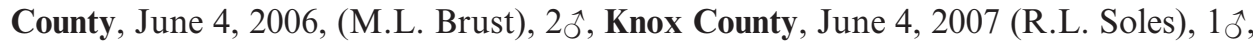
Pawnee County, July 2, 2005, (M.L. Brust), 1Q, Phelps County, June 11, 2005, (F.L.

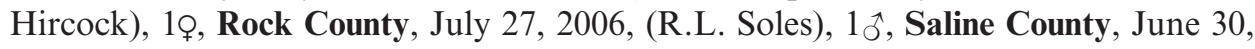
2007, (M.L. Brust), 1ð̄. 
Nebraska specimens in USDA collection: 139

* Psinidia fenestralis (Serville)

Bruner (1897) reported this grasshopper as rare in northwestern Nebraska but the record was questioned by Hebard (1925) and disregarded. As this is primarily an eastern species, such a record would be unlikely. It has, however, been collected commonly from several sites near the Platte River in central Nebraska as well as near Cherry Creek in northeastern Buffalo County. It inhabits low lying sandy areas with sparse vegetation. Peak numbers occur from late July to mid September.

PREVIOUS RECORDS: Bruner 1897, Hebard 1925.

SPECIMENS EXAMINED: Buffalo County, September 10, 2005, (M.L. Brust),

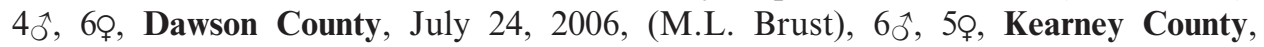
September 10, 2005, (M.L. Brust), 50̄, 4ㅇ․

NEW STATE RECORD

Nebraska specimens in USDA collection: 97

\section{Spharagemon bolli Scudder}

This species occurs in open woodlands and canyons in the western part of the state, and in oak savannas toward the east. It has only been found rarely in the eastern part of the state. It is common at Waubonsie State Park in Fremont County, Iowa, approximately $10 \mathrm{~km}$ east of Nebraska City, but has not been found in nearby areas in Nebraska. It is likely that habitat loss has largely depleted this species in the east. Peak numbers occur from July to September.

PREVIOUS RECORDS: Hagen 1970.

SPECIMENS EXAMINED: Douglas County, September 4, 1935, (collector

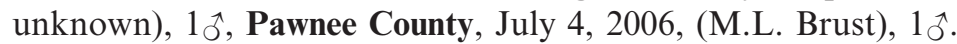

Nebraska specimens in USDA collection: 1

\section{Spharagemon campestris (McNeill)}

This species occurs primarily on dry hilltops in the panhandle counties. It can be locally common. Peak numbers occur in July and August.

PREVIOUS RECORDS: Hagen 1970.

Nebraska specimens in USDA collection: 7

\section{Spharagemon collare (Scudder)}

This is a very common bandwing in sandy grassland areas. It is abundant in the sandhills and occurs throughout the state wherever suitable habitat occurs. Peak numbers occur from mid-July to early September.

PREVIOUS RECORDS: Hauke 1953, Hagen 1970, Hagen and Rabe 1991.

SPECIMENS EXAMINED: Boyd County, August 9, 2007, (R.L. Soles), 1ô, Dodge County, October 3, 2006, (S.M. Spomer), 1o, Hall County, July 1, 2006, (M.L. Brust), 1ð̊, Howard County, July 29, 2005, (M.L. Brust, 1 Q.

Nebraska specimens in USDA collection: 183

\section{Spharagemon equale (Say)}

This is a common bandwing in shortgrass habitats in the panhandle, but it appears restricted to eroded hillsides and road cuts toward the east. It has been recorded from scattered locations throughout Nebraska. It prefers heavier soils than $S$. 
collare, and is largely lacking from the sandhills. It has previously been listed as Trimerotropis campestris. It appears to be attracted to lights as a single female was collected at a light at Bridgeport in Morrill County in 2007. Peak numbers occur from mid-July to early September.

PREVIOUS RECORDS: Hauke 1953, Hagen 1970, Hagen and Rabe 1991.

SPECIMENS EXAMINED: Gage County, October 7, 2006, (M.L. Brust), 1^^, Howard County, October 8, 2005, (M.L. Brust), 2§ิ, Knox County, July 14, 2006, (R.L. Soles), $1 \hat{\jmath}$.

Nebraska specimens in USDA collection: 50

\section{Trachyrhachys aspersa Scudder}

Hagen (1970) reported this species from much of the Nebraska panhandle, but it has rarely been collected there recently. It may be overlooked as it occurs late in the season. Hagen (1970) reports peak numbers in late August and September.

PREVIOUS RECORDS: Hauke 1953, Hagen 1970.

Nebraska specimens in USDA collection: 1

\section{Trachyrhachys kiowa (Thomas)}

This is a common species in areas of shortgrass throughout Nebraska. High densities can be indicative of overgrazed or unproductive range. Peak numbers occur from early July to early September.

PREVIOUS RECORDS: Hauke 1953, Mulkern et al. 1969, Hagen 1970, Hagen and Rabe 1991.

SPECIMENS EXAMINED: Harlan County, August 22, 2006, (R.L. Soles), 1ðَ, Holt County, August 3, 2005 (R.L. Soles), 1へર, Howard County, June 27, 2006, (S.

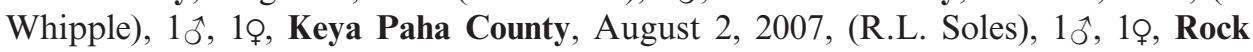
County, July 25, 2005, (R. L. Soles), 1 \%.

Nebraska specimens in USDA collection: 185

\section{Trimerotropis agrestis McNeill}

This grasshopper appears limited to the western half of Nebraska. It occurs in sparsely vegetated dry, sandy areas. Recent collections have been from large sand blowouts and the dunes that have developed around Lake McConaughy. It is abundant at Lake McConaughy, and some individuals there exhibit characters intermediate between T. agrestis and T. maritima. Peak numbers occur from early July to early September.

PREVIOUS RECORDS: Hauke 1953, Hagen 1970.

SPECIMENS EXAMINED: Keith County, July 12, 2005, (M.L. Brust), 3ð^, 1o.

Nebraska specimens in USDA collection: 46

\section{Trimerotropis cincta (Thomas)}

This species is known from Nebraska by a several specimens collected in Sioux County prior to 1910. It has not been found in Nebraska since despite intense efforts by Hagen (1970). It might still occur in the rocky, wooded canyons of the Pine Ridge.

PREVIOUS RECORDS: Hauke 1953.

Nebraska specimens in USDA collection: 0 


\section{Trimerotropis fratercula McNeill}

Hagen (1970) recorded this species from most of the panhandle counties. It has not been collected since. It apparently prefers rocky or clayey outcroppings in forested areas. Most Nebraska records are from August and September.

PREVIOUS RECORDS: Hauke 1953, Hagen 1970.

Nebraska specimens in USDA collection: 0

\section{Trimerotropis latifasciata Scudder}

Hagen (1970) reported that this species often occurs alongside $T$. pistrinaria. It has been collected throughout the panhandle counties. Hagen and Rabe also report in from McPherson County. Recent collections have not found it alongside $T$. pistrinaria, but rather alongside T. sparsa, in adobe badlands north of the Pine Ridge. Most Nebraska records are from August.

PREVIOUS RECORDS: Hauke 1953, Hagen 1970, Hagen and Rabe 1991.

Nebraska specimens in USDA collection: 7

\section{Trimerotropis maritima (Harris)}

This species was previously called Trimerotropis citrina Scudder. It appears to occur throughout Nebraska on moist bare sand. It is often abundant on river sandbars and along lake beaches. Bruner (1897) reported it as being attracted to lights. Peak numbers occur from early July to mid-September.

PREVIOUS RECORDS: Bruner 1897 (no county records).

SPECIMENS EXAMINED: Buffalo County, September 10, 2005, (M.L. Brust), 1@, Cass County, no date, (no collector name), 1ðิ, Dawson County, June 19, 2006,

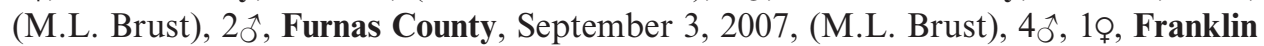
County, July 29, 1947, (H.A. Hauke), 1 ^઼, Hall County, July 4, 1933, (H.A. Hauke), 1乞ิ, Harlan County, July 21, 2005, (M.L. Brust), 1o, Kearney County, August 18,

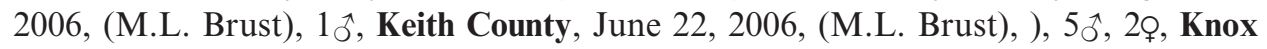
County, no date, (M.H. Swenk), 1今̄, Lancaster County, October 16, 2005, (M.L.

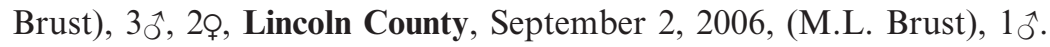

Nebraska specimens in USDA collection: 103

\section{Trimerotropis pallidipennis (Burmeister)}

This bandwing has been collected mostly in the western third of Nebraska. A recent collection from along the Platte River in Buffalo County represents a likely stray. At that site it was found among large numbers of T. maritima. Trimerotropis pallidipennis is known to migrate frequently and is often attracted to lights. Adults have been collected in Nebraska from mid-May to late October.

PREVIOUS RECORDS: Hauke 1953, Hagen 1970.

SPECIMENS EXAMINED: Box Butte County, July 11, 2007, (D. A. Widhalm), 1Q, Buffalo County, August 18, 2006, (M.L. Brust), 1Q, Hitchcock County, May 18,

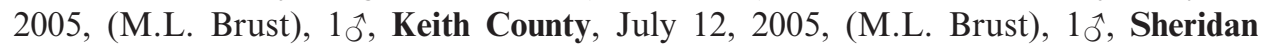
County, July 19, 2005, (M.L. Brust), 1 . .

Nebraska specimens in USDA collection: 9 


\section{Trimerotropis pistrinaria Saussure}

This species has been found throughout the panhandle as well as in Dundy County. It can be locally abundant on eroded clayey or gravelly hillsides. Most Nebraska records are from July to September.

PREVIOUS RECORDS: Hauke 1953, Hagen 1970.

Nebraska specimens in USDA collection: 36

\section{Trimerotropis salina $\mathrm{McNeill}$}

This bandwing occurs exclusively in saline areas in Nebraska. It is usually abundant along the edges of saline ponds in Morrill and Sheridan Counties and should be looked for in Garden and Scotts Bluff Counties. Lincoln represents the type location for the species. Extant populations in the Lincoln area are small and severely depleted. No studies have yet been done to determine if the Lincoln populations of this grasshopper may represent a unique subspecies. However, there are no obvious morphological differences between the Lincoln populations and those from the Nebraska panhandle. Peak numbers occur from mid-July to early September.

PREVIOUS RECORDS: Hauke 1953.

SPECIMENS EXAMINED: Morrill County, July 13, 2005, (M.L. Brust), 30ิ, 1\%, Sheridan County, July 19, 2005, (M.L. Brust), 6수, 5o .

Nebraska specimens in USDA collection: 66

Trimerotropis sparsa (Thomas) This species is limited to badland areas north of the Pine Ridge in Sioux and Dawes Counties in Nebraska. It is different from other Nebraska Trimerotropis species in having pale bluish hindwings; all others have yellow hindwings with a blackish band. Hagen (1982) compared numerous Nebraska specimens of $T$. sparsa and found the dark hind wing band is most often poorly developed, but may occasionally be prominent. Most Nebraska collections are from July and August.

PREVIOUS RECORDS: Hauke 1953, Hagen 1970.

Nebraska specimens in USDA collection: 24

\section{Tropidolophus formosus (Say)}

This species is known from four specimens collected in Dundy and Red Willow Counties. It has not been collected in Nebraska since 1937. Future collections may reveal that it still occurs in the extreme southwestern part of the state. Nebraska collections are from August and September.

PREVIOUS RECORDS: Hauke 1953.

Nebraska specimens in USDA collection: 0

\section{Xanthippus corallipes (Haldeman)}

This bandwing is common in the panhandle in shortgrass rangeland, but there are scattered records from the middle of Nebraska. Peak numbers occur from mid-April to mid-June.

PREVIOUS RECORDS: Hauke 1953, Hagen 1970, Hagen and Rabe 1991.

SPECIMENS EXAMINED: Furnas County, June 22, 2005, (M.L. Brust) 10^.

Nebraska specimens in USDA collection: 73 


\section{Xanthippus montanus (Thomas)}

This is a rare species in Nebraska. Recent records are mostly from sandy areas with sparse vegetation and sand blowouts. It likely occurs in scattered locations throughout the panhandle and sandhills, but is seldom encountered in numbers.

PREVIOUS RECORDS: Hauke 1953, Hebard 1925.

SPECIMENS EXAMINED: Brown County, May 31, 2007 (R.L. Soles), 1o, Garden County, May 25, 2006, (M.L. Brust) 1ㅅ, Keith County, July 26, 2006, (M.L. Brust), 1@, Kimball County, June 8, 2007 (M.L. Brust), 1ðึ, Morrill County, May 22, 2007, (D.A. Widhalm), 1o, Sheridan County, May 23, 2007, (D.A. Widhalm), 1수, 1 . Nebraska specimens in USDA collection: 14

\section{Romaleidae}

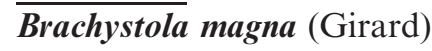

This is the lone Nebraska representative of the Romaleidae. This is the very large and unmistakable species often called "homesteaders" by local ranchers. Despite their large size they are not range-destructive and prefer sunflower. It currently occurs across the western two-thirds of Nebraska, but an old Lancaster County record suggests it may have once ranged into the eastern part of the state. Peak numbers occur from mid-July to early September.

PREVIOUS RECORDS: Hauke 1953, Hagen 1970, Hagen and Rabe 1991.

SPECIMENS EXAMINED: Boyd County, August 18, 2005, (R.L. Soles), 1へ, 1o, Hitchcock County, August 1, 2007, (G.L. Thorson), 1क, Holt County, July 6, 2005, (M.L. Brust), 1 nymph.

Nebraska specimens in USDA collection: 57 